\title{
Recent Developments in Accelerated Antibacterial Inactivation on 2D Cu-Titania Surfaces under Indoor Visible Light
}

\author{
Sami Rtimi *, Cesar Pulgarin and John Kiwi * \\ Ecole Polytechnique Fédérale de Lausanne, EPFL-SB-ISIC-GPAO, Station 6, CH-1015 Lausanne, Switzerland; \\ cesar.pulgarin@epfl.ch \\ * Correspondence: sami.rtimi@epfl.ch (S.R.); john.kiwi@epfl.ch (J.K.); Tel.: +41-21-69-36150 (S.R. \& J.K.) \\ Academic Editor: Naba Dutta \\ Received: 15 September 2016; Accepted: 23 January 2017; Published: 6 February 2017
}

\begin{abstract}
This review focuses on $\mathrm{Cu} / \mathrm{TiO}_{2}$ sequentially sputtered and $\mathrm{Cu}-\mathrm{TiO}{ }_{2}$ co-sputtered catalytic/photocatalytic surfaces that lead to bacterial inactivation, discussing their stability, synthesis, adhesion, and antibacterial kinetics. The intervention of $\mathrm{TiO}_{2}, \mathrm{Cu}$, and the synergic effect of $\mathrm{Cu}$ and $\mathrm{TiO}_{2}$ on films prepared by a colloidal sol-gel method leading to bacterial inactivation is reviewed. Processes in aerobic and anaerobic media leading to bacterial loss of viability in multidrug resistant (MDR) pathogens, Gram-negative, and Gram-positive bacteria are described. Insight is provided for the interfacial charge transfer mechanism under solar irradiation occurring between $\mathrm{TiO}_{2}$ and $\mathrm{Cu}$. Surface properties of $2 \mathrm{D} \mathrm{TiO}_{2} / \mathrm{Cu}$ and $\mathrm{TiO}_{2}-\mathrm{Cu}$ films are correlated with the bacterial inactivation kinetics in dark and under light conditions. The intervention of these antibacterial sputtered surfaces in health-care facilities, leading to Methicillin-resistant Staphylococcus Aureus (MRSA)-isolates inactivation, is described in dark and under actinic light conditions. The synergic intervention of the $\mathrm{Cu}$ and $\mathrm{TiO}_{2}$ films leading to bacterial inactivation prepared by direct current magnetron sputtering (DCMS), pulsed direct current magnetron sputtering (DCMSP), and high power impulse magnetron sputtering (HIPIMS) is reported in a detailed manner.
\end{abstract}

Keywords: magnetron sputtering; high power impulse magnetron sputtering (HIPIMS); bacterial inactivation kinetics; $\mathrm{Cu}-\mathrm{TiO}_{2}$ synergic effects; interfacial charge transfer (IFCT)

\section{Introduction}

The focus of innovative antibacterial materials is to find composites in colloid form or deposited on surfaces that are able to inactivate bacteria/pathogens within very short times and that have long operational lifetimes (high stability) [1-5]. Biofilms that spread bacteria in hospitals, schools, and public places are the most common and dangerous forms of infection by pathogens: bacteria, fungi, and viruses. Pathogens are capable of living in any environment where the minimal conditions of life are encountered, since they have the ability to form biofilms, adhering to each other and to surfaces. These pathogenic bacteria are continuously spread in closed environments, most commonly in health facilities [6-14]. Healthcare associated infections (HCAIs) are becoming a worldwide problem since bacteria can survive on abiotic surfaces for a long time. In this way, they disseminate a wide range of infections. The Center for Disease Control and Prevention (CDC) estimates that approximately two million patients/year are affected by HCAIs in the USA [15,16]. In Europe, HCAIs affect 3.2 million patients/year, and lead to mortality or an increase of the duration of a hospital stay and associated costs [17]. Nosocomial infection occurs by simply touching the hands of healthcare workers or by hospital clothing, equipment, air conditioners, and hospital water distribution networks [18]. The use 
of gloves, gowns, and masks, as well as patient isolation, have limited the spread of infections, but by themselves are not able to prevent the transmission of HCAIs [19,20].

The levels of contamination in UK hospitals have been reported to be $\sim 10^{5} \mathrm{CFU} / \mathrm{cm}^{2}$ in diabetic wound dressing rooms, and in hospital residence rooms a density of $10^{2} \mathrm{CFU} / \mathrm{cm}^{2}$ was found. This review will address several studies on surfaces coated with $\mathrm{TiO}_{2}, \mathrm{Cu}$, and $\mathrm{Cu} / \mathrm{TiO}_{2}$ that have the potential to decrease the environmental bacterial density in hospital facilities. The added benefit of these coatings is that they avoid, to a certain degree, biofilm formation [21-26]. When HCAIs are caused by multidrug-resistant (MDR) pathogens this problem becomes critical, since antibiotics are not available or are ineffective due to their prolonged application times, making the pathogens resistant to their initially designed abatement effect.

At the present time, more work is required to improve antibacterial coatings that induce fast bacterial reduction, and have high adhesion, robust layered structures, and stability precluding HCAIs. The application of nanotechnology to produce innovative 2D biomaterial surfaces that are useful in medicine possesses a significant potential for the prevention and treatment of infections. Nevertheless, concerns exist about the use of these new nanoparticulate materials due to the incomplete knowledge of their toxicology $[27,28]$.

The present write-up reviews the recent work on $\mathrm{TiO}_{2}, \mathrm{Cu}$, and the recent films made by $\mathrm{Cu}$ and $\mathrm{TiO}_{2}$ that lead to fast bacterial inactivation kinetics precluding partial or total biofilm formation. The spread of pathogenic infections will be decreased depending on the type of pathogen or its local concentration. Biofilm formation is the origin of $80 \%$ of all microbial infections in the body, making biofilms a primary health concern [6-14]. Biofilm pathogens adhere to a host surface, organize their community structure, and remain there by producing an extra-cellular polysaccharides (EPS) polymer matrix to cement the biofilm to the support in a permanent way. In the present review, the co-sputtered films of $\mathrm{Cu}$ and $\mathrm{Ti}$ will be designated as $\mathrm{Cu}-\mathrm{TiO}_{2}$ and the sequentially sputtered films ( $\mathrm{TiO}_{2}$ sputtered first, followed by $\mathrm{Cu}$ sputtering) will be designated as $\mathrm{Cu} / \mathrm{TiO}_{2}$. We report $\mathrm{Cu}-\mathrm{TiO}_{2}$ inactivation of E. coli and Methicillin-resistant Staphylococcus Aureus (MRSA), a bacteria strain resistant to the effect of antibiotics and to a lesser degree, to the abatement of other bacteria. What makes the problem even more complicated is that bacteria embedded in a biofilm can survive concentrations of antiseptic/antibiotics that are several times higher than the concentration able to kill planktonic cells of the same species [29].

\section{Bacterial Inactivation Performance on $\mathrm{TiO}_{2} / \mathrm{Cu}$ and Surface Properties}

\subsection{Short Description of the Main Issues of Concern Affecting the $\mathrm{TiO}_{2}$ Photocatalysis Application in Microbial Abatement}

After the seminal report by Matsunaga et al. [30], a large number of papers appear devoted to the issue of microbial abatement in suspension or on supported $\mathrm{TiO}_{2}$ surfaces. Lately, some reviews/monographs/reports have appeared on $\mathrm{TiO}_{2}$ photocatalysis involving a large-scale effort addressed to: (a) the reporting of the references on $\mathrm{TiO}_{2}$ photocatalysis; (b) the classification of the available data; and (c) proof of validity of the reported data by the recent reviews.

Foster et al. have reported on the $\mathrm{TiO}_{2}$ mediated disinfection of a large variety of pathogens [31]. The main barriers to the application of $\mathrm{TiO}_{2}$ photocatalysis in suspension have been recently reported by Guillard et al. [32], Morawski et al. [33], Robertson et al. [34], Dalrymple et al. [35], and Gamage et al. [36]. Reviews on the antimicrobial mechanism mediated by $\mathrm{TiO}_{2}$ composite films and suspensions haves been reported by several groups such as Kubacka et al. [37] and Dalrymple et al. [38]. $\mathrm{TiO}_{2}$, upon band-gap light irradiation, photogenerates charges that react with adsorbed $\mathrm{O}_{2}$ and $\mathrm{H}_{2} \mathrm{O}_{\text {vapor }}$ (at the solid-air interface), leading to reactive oxygen species (ROS) that present a high oxidation potential to degrade organic compounds and bacteria $[39,40]$. These (ROS) radicals are HO${ }^{\bullet}$, $\mathrm{O}_{2}{ }^{\bullet-}$, and $\mathrm{HO}_{2}{ }^{\bullet}$, and have been documented and characterized for most of their properties such as concentration, lifetimes, spectra, and redox potentials by numerous researchers. Linsebigler et al. [41], Nakano et al. [42], Fujishima et al. [43], Douad et al. [44], Griesser et al. [45], and Hu et al. [46] reported 
the photocatalytic activity of $\mathrm{TiO}_{2}$ thin films. However, more work using fast kinetics by femto- and picosecond spectroscopy in the visible region is still necessary to identify the nature and lifetime of these ROS species intervening in the individual pathogen inactivation. Recent works involving the fast kinetics of surfaces producing ROS under visible light that lead to subsequent $E$. coli inactivation have been reported recently by Kiwi et al. [47] and Rtimi et al. [48].

Photocatalytic degradation of pollutants and bacteria mediated by $\mathrm{TiO}_{2}$ is a promising approach to face the increasing environmental contamination. However, because of its wide band gap $(3.2 \mathrm{eV})$ $\mathrm{TiO}_{2}$ can absorb mostly UV-light $(\lambda<387 \mathrm{~nm})$ and only about $4 \%-5 \%$ of the visible radiation of the solar spectrum. Sensitization of $\mathrm{TiO}_{2}$ modification by $\mathrm{S}$ or $\mathrm{N}$ anions, or metal/oxides such as $\mathrm{Cu} / \mathrm{CuO}$ has been used to extend the $\mathrm{TiO}_{2}$ response into the visible region. In this way, accelerated $\mathrm{TiO}_{2}$ reaction kinetics under visible light, leading to bacterial inactivation on doped $\mathrm{TiO}_{2}$, binary oxides, $\mathrm{TiO}_{2}$ composites, or decorated 2D-surfaces, have been recently reported by Dionysiou et al. [49,50], Pillai et al. [51-53], Rtimi et al. [48], Kavitha et al. [54], Fotiou et al. [55], and Bahneman et al. [56].

Wettability plays an important role on the $\mathrm{TiO}_{2}$ surface under band-gap irradiation. The surface wettability is evaluated by the water contact angle (CA). The CA $(\theta)$ is defined as the angle between the solid surface and the tangent line of the aqueous solution at the liquid-solid interface. Hashimoto, Fujishima, et al. $[57,58]$ reported the importance of the hydrophilicity changes in $\mathrm{TiO}_{2}$ under band-gap irradiation on the $\mathrm{TiO}_{2}$ surface during pollutant/bacteria degradation. A hydrophobic $\mathrm{TiO}_{2}$ surface at time zero was reported to become highly hydrophilic or superhydrophilic $\left(\theta<5^{\circ}\right)$ under band-gap excitation. This surface will gradually revert to the original surface after relatively long periods in the dark. This consideration is important in bacterial inactivation processes, since highly hydrophilic conversions lead to clean surfaces due to the destruction of bacteria adsorbed on the $\mathrm{TiO}_{2}$ surface during the sample irradiation. The photo-generated holes have been shown to be responsible for the $\mathrm{TiO}_{2}$ surface conversion to a highly hydrophilic surface. These holes (a) diffuse to the $\mathrm{TiO}_{2}$ surface and to the oxygen lattice sites reacting with bacteria or $(b)$ produce $\mathrm{HO}^{\bullet}$-radicals reacting with the embedded $\mathrm{HO}^{\bullet}$ on the $\mathrm{TiO}_{2}$ surface. However, a part of the photo-generated holes break the -Ti-Olattice bonds by coordinating $\mathrm{H}_{2} \mathrm{O}$ at the Ti-lattice sites. The coordinated water releases a proton (charge compensation) and a new $\mathrm{HO}^{\bullet}$ is formed, increasing the number of surface $\mathrm{HO}^{\bullet}$ radicals [59].

Transparent, non-scattering PE (PE = polyethylene), sputtered by direct current magnetron sputtering (DCMS) for $8 \mathrm{~min}$ with $\mathrm{TiO}_{2}$ thin film, inactivated E. coli within one hour under low intensity solar simulated irradiation $\left(52 \mathrm{~mW} / \mathrm{cm}^{2}\right)$. The scheme of the sputtering unit is shown in Figure 1. The PE was pretreated for $15 \mathrm{~min}$ by RF-plasma to graft a larger amount of polar negative

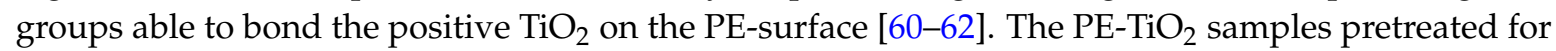
$15 \mathrm{~min}$ and sputtered for $8 \mathrm{~min}$ presented the highest amount of $\mathrm{TiO}_{2}$ sites in exposed positions, leading to the favorable bacterial inactivation kinetics. A decrease from the initial contact angle (CA) of $\mathrm{PE}-\mathrm{TiO}_{2}$ at time zero and $\sim 121^{\circ} \mathrm{C}$ to $\theta<5^{\circ}$ within 60 min of irradiation, inducing $\mathrm{PE}-\mathrm{TiO}_{2}$ super-hydrophilicity, was observed to be concomitant with the time of bacterial inactivation. This seems to be a necessary condition to attain the optimal E. coli inactivation kinetics. Samples sputtered for times $>8$ min led to a thicker coating, inducing charge bulk inward diffusion that decreased the charge transfer between the ${\mathrm{PE}-\mathrm{TiO}_{2}}_{2}$ and bacteria [63]. The rate of the hydrophobic to hydrophilic transformation was found to be $0.28 \mathrm{~min}^{-1}$. The reverse reaction rate in the dark was found to be $8.7 \times 10^{-3} \mathrm{~min}^{-1}$. The reverse reaction time necessary to reach the initial hydrophobic CA $\sim 121^{\circ}$ was completed within about $24 \mathrm{~h}$. These rates were calculated by integrating $\cos \theta$ in the Young's equation $[58,59]$.

$\mathrm{TiO}_{2}$ sputtering for $8 \mathrm{~min}$ led to a $\mathrm{TiO}_{2}$ loading with the most suitable thickness for the charge diffusion generated in the $\mathrm{TiO}_{2}$ to reach the bacteria. No bacterial re-growth was observed, meaning that there were no bacteria adhered to the surface after the inactivation cycle. After each cycle, the samples were washed with distilled water and dried. Then, the samples were kept in an oven at $60{ }^{\circ} \mathrm{C}$ to avoid bacterial contamination. After washing, the $\mathrm{PE}-\mathrm{TiO}_{2}$ samples were left standing for $24 \mathrm{~h}$ to regain the initial hydrophobicity. 


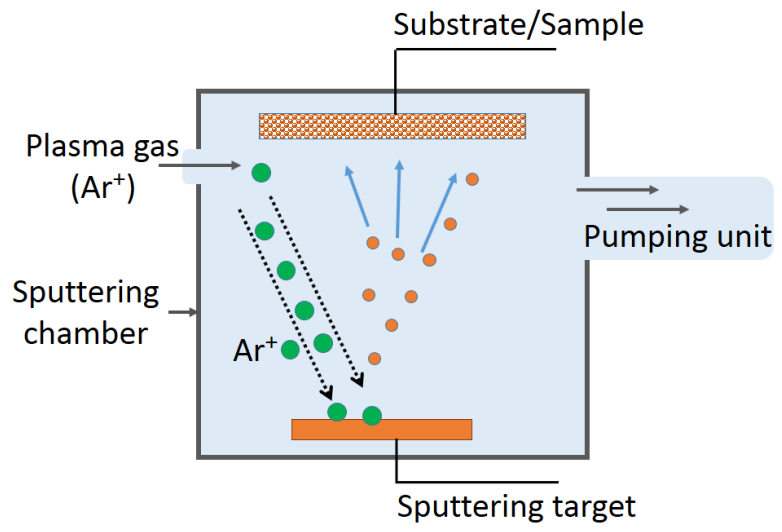

Figure 1. Sputtering unit used during the sputtering of antibacterial layers on diverse substrates.

According to Young's theory, the $\cos \theta$ of a liquid droplet on a solid is a function of the interfacial energy between the solid and the liquid. The wettability is commonly evaluated in terms of the contact angle (CA), which is given by Young's equation [58]:

$$
\gamma S=\gamma S L+\gamma L \cdot \cos \theta
$$

In Equation (1), $\gamma S$ and $\gamma L$ are the surface free energies per unit area of the solid and the liquid, respectively, and $\gamma S L$ is the interfacial free energy per unit area. In addition, $\gamma S L$ can be approximated using the Girifalco-Good Equation (2), with $\gamma S$ and $\gamma L$, as:

$$
\gamma S L=\gamma S+\gamma L-\Phi(\gamma S / \gamma L)^{1 / 2}
$$

Here, $\Phi$ is a constant parameter ranging from 0.6 to 1.1, depending on the solid. In addition, $\gamma L$ is the water surface free energy, which has a constant value of $74 \mathrm{~mJ} / \mathrm{m}^{2}$. Therefore, by combining Equations (1) and (2), the CA can be simply expressed as:

$$
\cos \theta=c \gamma S^{1 / 2}-1(c: \text { constant })
$$

The highly hydrophilic state generated by UV light gradually returns to the initial hydrophobic state in the dark. The initial contact angle on RF-pretreated DCMS sputtered $\mathrm{PE}-\mathrm{TiO}_{2}$ samples decreased to an angle $<5^{\circ}$ within $60 \mathrm{~min}$ of irradiation. The hydrophobic or hydrophilic nature of a surface is important for the adhesion of bacteria to a $\mathrm{TiO}_{2}$ layered surface and for regulating the subsequent light or dark induced kinetic bacterial inactivation.

E. coli and Staphylococcus aureus present a preferential adhesion to hydrophilic surfaces [32,64-67]. Efficient antimicrobial activity on $\mathrm{Cu}$-surfaces has been recently reported against methicillin-resistant Staphylococcus aureus (MRSA) and the bacterial reduction was evaluated by four methods. A reduction of $4 \log _{10}$ in the initial MRSA concentration of $10^{6} \mathrm{CFU}$ was found for ten clinical MRSA isolates within $1 \mathrm{~h}$, suggesting the suitability of the $\mathrm{Cu}$-surfaces in preventing the transmission of these gram-positive bacteria [64]. The loss of viability testing was performed by combining the data obtained by direct transfer on agar plates and stereomicroscopy. Two different methods were used to evaluate the bactericidal activity of the Cu-sputtered samples.

Bacteria with hydrophobic surface properties such as S. epidermis adhere preferentially to hydrophobic surfaces [66]. Hydrophobic bacteria such as E. coli, with an initial contact angle of $121^{\circ}$ reduced to less than $5^{\circ}$ (full hydrophilicity) have been reported within 5-10 $\mathrm{min}$. E. coli was shown to adhere to $\mathrm{Cu}$ and $\mathrm{TiO}_{2}-\mathrm{Cu}$ surfaces $[40,46,60,61,67]$. The negative charge on the catalyst/photocatalyst sputtered surface on $\mathrm{TiO}_{2}, \mathrm{TiO}_{2}-\mathrm{Cu}$, and $\mathrm{TiO}_{2}-\mathrm{ZrO}_{2}$-polyester (PES) surfaces is outlined below in Equations (5)-(9): 


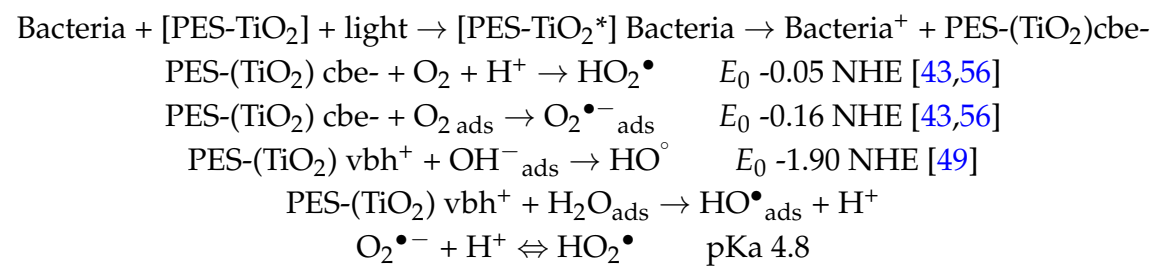

In reaction (2), the $\mathrm{HO}_{2} \bullet$ radical is stable at $\mathrm{pH}<4.8$, and above this $\mathrm{pH}$, more than $50 \%$ is present in the form of $\mathrm{O}_{2}{ }^{\bullet-}$, as noted in Equation (9).

Most of the bacteria acquire a negative electric charge in aqueous suspension or in the presence of air humidity, and this aspect has been revealed to be important in bacterial adhesion to charged surfaces [68]. It has been known for a long time that surfaces with high surface energies, such as the ones encountered in hydrophilic surfaces, are to a great extent negative and develop resistance to bio-adhesion $[69,70]$. These two last considerations have to be considered from case-to-case when inactivating a specific pathogen on a well-defined antibacterial surface [6-13].

In the last 30 years, the $\mathrm{TiO}_{2}$ mediated photocatalytic inactivation of pathogens has been the focus of bacterial disinfection studies. Inactivation by $\mathrm{TiO}_{2}$ suspensions, supported photocatalysts, and nano-rods under diverse light sources has been reported within minutes/hours [71]. In dark control experiments, $\mathrm{TiO}_{2}$ has been reported to exert no microbial inactivation or very low antibacterial activity. Recently, research has provided evidence that selected experimental conditions $\left(\mathrm{pH}, \mathrm{TiO}_{2}\right.$ amount and particle size, bacterial concentration) below the $\mathrm{TiO}_{2}$ isoelectric point led to $10^{4} \mathrm{CFU} / \mathrm{mL}$ E. coli inactivation in the dark within $120 \mathrm{~min}$. This was about $50 \%$ of the E. coli inactivation induced under the same experimental conditions when applying a UV-light centered at $366 \mathrm{~nm}$. No photo-generated electrons/holes or ROS were present in the absence of band-gap irradiation [71]. This work showed that the electrostatic and or Coulomb interaction at $\mathrm{pHs}$ between 4 and 4.5 suppresses the division of bacteria leading to $E$. coli loss of cultivability.

A subsequent study presenting evidence for the lack of cultivability in the dark due to the interaction between $\mathrm{TiO}_{2}$ surfaces in the minute range has been recently reported [72]. The bacterial cells interaction with $\mathrm{TiO}_{2}$ aggregates was followed by electron microscopy. The interaction of the $\mathrm{TiO}_{2}$ in the dark with $E$. coli led to cell wall damage/inactivation due to electrostatic forces competing with Van der Waals forces occurring at physiological $\mathrm{pH}$-values and inducing damage/deformation in the cell-wall packing structure, with an increase of the membrane permeability. $\mathrm{TiO}_{2}$-polyester samples demonstrated repetitive bacterial inactivation (loss of cultivability) in the dark. Bacterial inactivation in the dark occurred within 120 min compared to the E. coli mediated $\mathrm{TiO}_{2}$ photocatalysis that occurred within 60 min under an actinic light Lumilux 18W/827 source (OSRAM GmbH, Winterthur, Switzerland), radiating within 350 and $740 \mathrm{~nm}$, with an intensity of $4.1 \mathrm{~mW} / \mathrm{cm}^{2}$. This study reports on an important issue in the field of disinfection technology. The $\mathrm{TiO}_{2}$-polyester led to disinfection processes being carried out in a repetitive way. This is a more convenient approach when compared to $\mathrm{TiO}_{2}$ suspensions where the $\mathrm{TiO}_{2}$ nanoparticles have to be removed from the solution after each cycle, not allowing for a continuous disinfection treatment. Therefore, $\mathrm{TiO}_{2}$-supported polyester surfaces show a practical potential to preclude pathogenic biofilm formation in the dark. Alteration of the E. coli cell permeability in contact with $\mathrm{TiO}_{2}$ in the dark has also been reported recently and the morphological changes of the bacteria were further documented by Guillard et al. [32]. The damage to the bilayer cell envelope was ascribed to the lipo-saccharide (LPS) packing structure damage. In contrast, $\mathrm{SiO}_{2}$ under the same conditions did not induce detrimental effects on the bacteria, inhibiting its reproduction due to the variance of the electrostatic charges/interaction at the reaction $\mathrm{pH}$. $\mathrm{TiO}_{2}$ nanoparticles present a potential risk of these particles to penetrate in tissues and biological membranes. Ecotoxicology of $\mathrm{TiO}_{2}$ has recently been addressed in several studies/reviews, which indicate the high stability of $\mathrm{TiO}_{2}$ nanoparticles with limited cytotoxic effects [27,73-76].

The way light is applied to $\mathrm{TiO}_{2}$ suspensions to inactivate bacteria has been reported recently in detail by Pulgarin et al. [77] to have significant effects on the inactivation kinetics. The way 
light is applied during bacterial disinfection may or may not lead to complete bacterial removal: continuous irradiation leads to a rapid removal of bacteria compared to the same light dose applied intermittently. No bacterial re-growth was observed after illumination of a contaminated $\mathrm{TiO}_{2}$ suspension. In contrast, without catalyst, illuminated bacteria in solution recovered their initial concentration after $3 \mathrm{~h}$ in the dark. In a subsequent study, $\mathrm{TiO}_{2}$ suspensions were shown to be effective in reducing E. coli when irradiated in the presence of a bacterial consortium. The inactivation rate was dependent on biological parameters such as physiological state, $\mathrm{pH}$, initial concentration of bacteria, and the organic/inorganic impurities/residues present in the solution. After illumination periods with different lengths, a "residual disinfecting effect" in the dark was observed after the light was turned off, as a function of the applied intensity $\left(40-100 \mathrm{~mW} / \mathrm{cm}^{2}\right)$. Enterococcus sp., a Gram-positive bacterium with cell-wall thicknesses between 30 and $80 \mathrm{~nm}$ appear to be less sensitive compared to coliforms and other Gram-negative bacteria with cell-wall thicknesses $10-20 \mathrm{~nm}$ to the effect of $\mathrm{TiO}_{2}$ under light [78].

Generally, the bacterial inactivation kinetics is determined by the hydrophobic-hydrophilic properties of the surface mediating the bacterial disinfection. For different processes involving $\mathrm{TiO}_{2}$ surfaces, the hydrophobic-hydrophilic conversion in air under solar light irradiation proceeds with shorter times compared to the time required for E. coli inactivation. References $[79,80]$ by

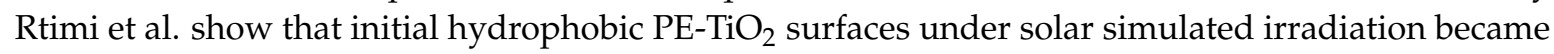
super-hydrophilic surface within times $<1 \mathrm{~h}$. The conversion of the initial hydrophobic surfaces (contact angle $>150^{\circ}$ ) to super-hydrophilic surfaces (contact angle $<5^{\circ}$ ) is accepted as a necessary condition but not the only necessary condition for bacterial inactivation on ${\mathrm{PE}-\mathrm{TiO}_{2}}_{2}$ surfaces. The PE-film presents a smooth surface that allows the measurement of sputtered $\mathrm{TiO}_{2}$ by applying different powers and conveniently follows the change in the dynamic contact angle measurements with time [81].

In $\mathrm{TiO}_{2}$ dispersions/suspensions made up of colloids or pre-formed powder nanoparticles, the photocatalysis led to many studies focusing on bacterial abatement [12,30-63,71,72] and showing the inactivation of spores [82-85], viruses [86], algae [87], and fungi [88]. $\mathrm{The}^{\mathrm{TiO}_{2}}$ suspensions, although successful in abating a variety of pathogens under light irradiation, require times that seem to be too long to treat large water volumes. The second inconvenience is the separation of the suspension from the bacterial residues after the disinfection process. This is expensive in terms of time, labor, and reagents. Therefore, some laboratories have begun to use supported $\mathrm{TiO}_{2}$ materials in disinfection processes mediated by $\mathrm{TiO}_{2}$. To avoid the separation step at the end of the bacterial abatement, Kuhn et al. [89] reported in 2003 that preformed $\mathrm{TiO}_{2}$ nanoparticles grafted on plexiglass surfaces inactivate E. coli under UV-light, but only to a small extent. Nevertheless, these surfaces showed a very heterogeneous (non-uniform) $\mathrm{TiO}_{2}$ coating. Generally, coating with colloidal $\mathrm{TiO}_{2}$ on thermal resistant substrates such as glass, iron plates, and ceramics provide layers that are not reproducible and can be wiped off by rubbing using naked hands [90].

The synthesis of uniform 2D-coatings on supports by applying direct current magnetron sputtering (DCMS), pulsed direct current magnetron sputtering (DCSMP), and highly ionized pulsed plasma magnetron sputtering (HIPIMS) have been reported to uniformly cover surfaces resistant to thermal stress. However, sputtering methods have been used to coat textiles such as cotton and polyester (PES) and low cost inert thin polymer films such as polyethylene (PE) that present low thermal stability $\leq 100-130{ }^{\circ} \mathrm{C}$ comprise $80 \%$ of the commercial market.

\section{2. $\mathrm{TiO}_{2} / \mathrm{Cu}$ Synthesis Leading to Uniform, Adhesive, and Antibacterial Films}

Physical vapor deposition (PVD) is carried out in a vacuum by condensation of a metal/non-metal vapor onto the support surface that is generally in the reaction chamber at a relatively low temperature. This method involves high temperature vacuum evaporation of the material to be coated on the support. Anatase layers have been deposited in this way, showing a super-hydrophilic behavior under band-gap irradiation as reported by several researchers in the field [91]. When using chemical vapor deposition (CVD), the substrate is exposed to volatile compounds that decompose on the substrate, 
leading to the desired coatings [92-94]. A uniform, thin, adhesive, robust $\mathrm{TiO}_{2}$ film has been deposited on glass [95] from Ti-chloride/ethyl-acetate at about $500{ }^{\circ} \mathrm{C}$. CVD is able to deposit continuous films without the need of a post-annealing process to crystallize the $\mathrm{TiO}_{2}$ nanoparticulates.

Diverse pulse magnetron sputtering (PMS) systems have been used to deposit $\mathrm{TiO}_{2}$ films with thicknesses of up to $300 \mathrm{~nm}$ and layers comprising mainly anatase at temperatures $\leq 130{ }^{\circ} \mathrm{C}$. Using this approach, textiles presenting low thermal resistance, thin polymer films, and polycarbonates (PC) have been coated with $\mathrm{TiO}_{2}, \mathrm{TiO}_{2}$-metal, and $\mathrm{TiO}_{2}$ metal-oxides [61,96-98]. The basic installation of a DCMS unit is shown in Figure 1.

One of the first reports on DCMS sputtered photocatalytic $\mathrm{TiO}_{2}$ on Si-wafers and ceramic targets was reported by Miron et al. [99]. The utility of $\mathrm{TiO}_{2}$ sputtered surfaces was already recognized many years ago. During the photocatalytic disinfection, the electron acceptor, $\mathrm{O}_{2}$, in contact with the sputtered $\mathrm{TiO}_{2}$, is readily available from the air and its concentration is normally replenished by the catalyst surface during disinfection. The efficiency of the antibacterial catalytic surface is influenced by the surface porosity, the intensity of the light, the sample roughness and uniformity, the type of bacteria (either Gram-negative or Gram-positive), the distance of the light source to the sputtered sample, the surface $\mathrm{pH}$, and the hydrophilic-hydrophobic balance of the sputtered sample.

\subsection{Cu-Loaded Sputtered Surfaces Active in the Dark and under Light, Leading to Microbial Abatement}

Antimicrobial nanoparticulate films preparation is a topic of increasing attention since its objective is to reduce or eliminate the formation of infectious bacteria biofilms leading to hospital acquired infections (HAI) [100]. However, more effective bacterial inactivation films on flat or complex 2D/3D surfaces are needed due to the increasing resistance of pathogenic bacteria to synthetic antibiotics administered for long periods of time. Additionally, nosocomial infections due to antibiotic resistant bacteria are becoming more frequent [25]. Surfaces sputtered by DCMS/DCMSP containing metals, oxides, or semiconductors (either heat resistant or not) have been reported recently, leading to effective, stable, and uniform bactericide films [101-103]. The recently developed highly ionized pulsed plasma magnetron sputtering (HIPIMS) leads to films by applying high electrical pulses of 1-10 A and up to $100 \mathrm{~V}$, which leads to layers that present superior resistance and compactness against corrosion and oxidation. The HIPIMS sputtering on 3D-complex objects addresses the problems encountered when depositing thin films on substrates by DCMS/DCMSP [102] since the adhesion of the sputtered films (by DCMS/DCMSP) is not very strong. This is due to the relatively low bias voltage applied on the substrate during the sputtering time [103]. HIPIMS sputtering induces a strong interaction with 2D/3D substrates due to the higher fraction of the $\mathrm{Cu}^{+} / \mathrm{Cu}^{2+}$-ions; up to $70 \%$ compared with DCMS/DCMSP [104]. The Cu-ions generated by DCMS were reported by Castro et al. [105] and by using X-ray Photo-electron Spectroscopy (XPS), evidence was shown for the $\mathrm{Cu}^{+} / \mathrm{Cu}^{2+}$ and $\mathrm{Cu}^{3+}$ ions. Subsequently, a larger amount of $\mathrm{Cu}$-ions was reported on a support by Osorio et al. after applying DCMSP [106]. More recently, a study using HIPIMS reported by Rtimi et al. [107] led to a significantly higher amount of $\mathrm{Cu}$-ions on the $\mathrm{Cu}$-PES surfaces, accelerating bacterial inactivation compared to DCMS and DCMSP. The relatively lower sputtering energies employed during DCMS and DCMSP sputtering would at first sight be a reason to expect a higher amount of $\mathrm{Cu}$-ions being able to leave the $\mathrm{Cu}$-PES surface and interact/stick to the outer cell wall of E. coli, and then diffuse through the porins and translocate to the cytoplasm, inducing bacterial inactivation/death. However, the opposite effect was observed. HIPIMS sputtering ionized $70 \%$ of the $\mathrm{Cu}{ }^{\bullet}$ to $\mathrm{Cu}$-ions in the HIPIMS chamber, leading to highly charged $\mathrm{Cu}$-ion surfaces. The higher amount of $\mathrm{Cu}$-ions later translocated through the $\mathrm{E}$. coli porins, inducing an accelerated bacterial inactivation [108].

The strong adherence of the sputtered atoms/ions on complex shape biased objects is due to the higher ion-arrival energy on the surface compared to the more traditional DC/DCP sputtering methods [104]. Cu-ions in ppb-amounts, besides electrostatically interacting with the bacterial envelope, lead to the partial unpacking/damage of the LPS of the outer E. coli bacterial cell wall, later penetrating the bacterial cell-porins with diameters of 1.1-1.3 nm [109]. Cu-ions will 
also diffuse through skin pores of $\sim 100 \mathrm{~nm}[6,12,27-31]$. To preclude the viral and diverse types of nosocomial infections caused by antibiotic resistant bacteria, Borkow and Gabbay have reported studies on Cu-loaded textiles [110-113]. These studies report in a detailed, systematic, and comprehensive way the preparation and evaluation of the pathogen abatement on these innovative surfaces. Furthermore, colloidal $\mathrm{Cu}$-coated textiles showing antibacterial properties were reported by Gedanken's group [114,115], focusing on $\mathrm{ZnO}$ and $\mathrm{CuO}$ colloids deposited on textiles by sonication. $\mathrm{Cu}$-colloids were impregnated on polyester (PES) to inactivate bacteria under low intensity sunlight. The PES was previously pre-treated by RF-plasma to increase the amount of negative carboxylic sites able to bond to $\mathrm{Cu}$-ions [116]. The non-uniform dispersion of the $\mathrm{Cu} / \mathrm{CuO}_{x}$ on the PES surface motivated us to work on the preparation of $\mathrm{Cu}$-antibacterial films by sputtering in order to obtain adhesive, uniform, and reproducible $\mathrm{Cu} / \mathrm{CuO}_{\mathrm{x}}$ coatings. In this way, we overcame the shortcomings of colloidally loaded PES and this work will be described in the paragraph below.

DCMS prepared samples were carried out with Cu-targets (99.9\%) from Lesker AG, Hastings, East Sussex, UK, and the textiles/thin polymer films were sputtered in a magnetron chamber at a pressure of 0.1-1 Pa. The distance between the $\mathrm{Cu}$-target and the substrate was $\sim 10 \mathrm{~cm}$, the deposition current was 30-250 mA, and the voltage was varied between 100 and $500 \mathrm{~V}$. The $\mathrm{Cu}$-film thickness was determined with a profilometer (Alphastep500, Tencor, Rocklin, CA, USA). Cu-DCMS sputtered for $40 \mathrm{~s}$ formed a $3 \mathrm{~nm}$ thick film (or 15 atomic layers) and led to the fastest $E$. coli inactivation [105]. The most favorable structure-reactivity $\mathrm{Cu}$-cluster agglomerates sputtered on cotton is defined as the $\mathrm{Cu}$-nanoparticulate on cotton, and led to the most favorable bacterial inactivation kinetics. During several studies on $\mathrm{Cu}, \mathrm{CuO}$, and $\mathrm{Cu} / \mathrm{TiO}_{2}$ sputtered nanoparticulates, it was shown that the $\mathrm{Cu}$-sputtering time or the amount of $\mathrm{Cu}$ sputtered on the substrate did not directly relate to the bacterial inactivation time [105-107,117-119]. From this it was concluded that the Cu-ions play an important role in mediating bacterial disinfection and these $\mathrm{Cu}$-ions were determined by $\mathrm{X}$-ray photoelectron spectroscopy (XPS).

The magnetic sputtering chamber contains Ar that upon impact of the applied current ionizes to $\mathrm{Ar}^{+}$

$$
\begin{gathered}
\mathrm{Ar} \rightarrow \mathrm{Ar}^{+}+\mathrm{e}^{-} \text {or } \mathrm{Ar}^{*}+\mathrm{e}^{-} \\
\mathrm{Ar}^{+}+\mathrm{Cu}^{\bullet} \rightarrow \mathrm{Cu}^{+}+\mathrm{Ar}^{\bullet} \\
\mathrm{e}^{-}+\mathrm{Cu}^{\bullet} \rightarrow \mathrm{Cu}^{+}+2 \mathrm{e}^{-}
\end{gathered}
$$

In Equation (12), the direct electron impact of highly energetic/high speed electrons kicks off an $\mathrm{e}^{-}$of the $\mathrm{Cu}$-target. The intensity of the $\mathrm{e}^{-}$collision with the $\mathrm{Cu}^{\bullet}$-target is proportional to the energy/current applied in the sputtering chamber. The Ar may also attain only excited states and ionize the $\mathrm{Cu}^{\bullet}$, as shown in Equation (13), because the Ar has a higher energetic content than the ionization energy necessary to ionize $\mathrm{CuO}$ by a process called penning ionization:

$$
\mathrm{Ar}^{*}+\mathrm{Cu}^{\bullet} \rightarrow \mathrm{Cu}^{+}+\mathrm{Ar}+\mathrm{e}^{-}
$$

The $\mathrm{Cu}$ ions produced in the Ar-plasma are accommodated on the substrate, leading to $\mathrm{Cu}$-films by epitaxial growth through nucleation, followed by growth that leads to atomic clusters/agglomeration/crystals that present metal/oxide character depending on their size and the growth symmetry $[21,117,120]$. The condensation of $\mathrm{Cu}$ and $\mathrm{Cu}$-ions necessary to form $\mathrm{Cu}$-films on the substrate involve the preference of $\mathrm{Cu}$-atoms for binding to other $\mathrm{Cu}$-atoms/ions rather than to the substrate, leading to agglomerates [121,122]. Depending on the Cu-sputtering time and energy, $\mathrm{Cu}$-clusters are formed that are not necessarily crystallographic, which depend on the affinity between the $\mathrm{Cu}$-atoms and the substrate. During the $\mathrm{Cu}$-atom/ions condensation/coalescence during the formation of the film, sometimes the Cu-nuclei merge on the substrate without forming grain boundaries [123,124]. 
Once the $\mathrm{Cu}$ clusters/atoms are on the surface of a substrate, they interact with $\mathrm{O}_{2}$ which leads to $\mathrm{CuO}$ or $\mathrm{Cu}_{2} \mathrm{O}[105-107,117,119-122,125-131]$. The oxidative state of the nanoparticulate $\mathrm{Cu}$ determines the bacterial mechanism/kinetics. The semiconductor character of $\mathrm{CuO}$ allows for the generation of photo-induced charges. The amount of these species is a function of the applied light dose. The $\mathrm{CuO}$ and $\mathrm{Cu}_{2} \mathrm{O}$ mechanistic steps inducing charge separation under band-gap irradiation, leading subsequently to bacterial inactivation, could be suggested as:

$$
\mathrm{CuO}+h v(\text { sunlight }) \rightarrow \mathrm{CuO}\left(\mathrm{cbe}^{-}\right), \mathrm{CuO}\left(\mathrm{vbh}^{+}\right)
$$

where $\mathrm{CuO}\left(\mathrm{cbe}^{-}\right)$refers to the conduction band electrons generated and the $\mathrm{CuO}$-semiconductor under band-gap irradiation, and $\mathrm{CuO}\left(\mathrm{vbh}^{+}\right)$are the holes generated concomitantly in the $\mathrm{CuO}$-valence band. Under photon energies exceeding the $\mathrm{CuO}$ band-gap, the $\mathrm{cbe}^{-}$electron could either react directly with the $\mathrm{O}_{2}$, forming $\mathrm{O}_{2}{ }^{-}$, or reduce the $\mathrm{Cu}^{2+}$ to $\mathrm{Cu}^{+}$as suggested below:

$$
\begin{gathered}
\mathrm{CuO}\left(\mathrm{cbe}^{-}\right)+\mathrm{O}_{2} \rightarrow \mathrm{CuO}+\mathrm{O}_{2}^{-} \\
\mathrm{CuO}\left(\mathrm{cbe}^{-}\right) \rightarrow \mathrm{CuO}\left(\mathrm{Cu}^{+}\right) \\
\mathrm{CuO}\left(\mathrm{Cu}^{+}\right)+\mathrm{O}_{2} \rightarrow \mathrm{CuO}\left(\mathrm{Cu}^{2+}\right)+\mathrm{O}_{2}^{-}
\end{gathered}
$$

The cbe $^{-}$in Equation (17) is produced by a $\mathrm{CuO}$ (p-type) with a band-gap energy of $1.7 \mathrm{eV}$, a flat-band potential of $-0.3 \mathrm{~V} \mathrm{SCE} \mathrm{(pH} \mathrm{7),} \mathrm{and} \mathrm{a} \mathrm{valence} \mathrm{band} \mathrm{at} \mathrm{+1.4} \mathrm{V} \mathrm{SCE} \mathrm{[56].}$

$$
\begin{gathered}
\mathrm{CuO}\left(\mathrm{Cu}^{+}\right) \rightarrow \mathrm{CuO} \text { vacancy }+\mathrm{Cu}^{+} \\
\mathrm{CuO}\left(\mathrm{vbh}^{+}\right)+\text {bacteria } \rightarrow \mathrm{CO}_{2}, \mathrm{H}_{2} \mathrm{O} \text {, inorganic } \mathrm{N}, \mathrm{S}
\end{gathered}
$$

The photocatalytic reactions for the $\mathrm{Cu}_{2} \mathrm{O}$ mediated bacterial inactivation are suggested in Equations (20)-(23). The highly mobile electrons first transfer from $\mathrm{Cu}_{2} \mathrm{O}\left(\mathrm{cbe}^{-}\right)$to the $\mathrm{TiO}_{2} \mathrm{cb}$ as suggested in Equation (21).

$$
\begin{gathered}
\mathrm{Cu}_{2} \mathrm{O}+\mathrm{hv} \rightarrow \mathrm{Cu}_{2} \mathrm{O}\left(\mathrm{cbe}^{-}\right), \mathrm{Cu}_{2} \mathrm{O}\left(\mathrm{vbh}^{+}\right) \\
\mathrm{Cu}_{2} \mathrm{O}\left(\mathrm{cbe}^{-}\right)+\mathrm{TiO}_{2} \rightarrow \mathrm{TiO}_{2}^{-} \text {or }\left(\mathrm{Ti}^{3+}\right) \\
\mathrm{TiO}_{2}^{-}+\mathrm{O}_{2} \rightarrow \mathrm{TiO}_{2}+\mathrm{O}_{2}^{-} \\
\mathrm{Cu}_{2} \mathrm{O}\left(\mathrm{vbh}^{+}\right)+\text {bacteria } \rightarrow \mathrm{CO}_{2}, \mathrm{H}_{2} \mathrm{O} \text {, inorganic } \mathrm{N}, \mathrm{S}
\end{gathered}
$$

Taking $0.3 \mathrm{~nm}$ as the distance between the $\mathrm{Cu}$-atoms on the film surface and the thickness of an atomic layer $\sim 0.2 \mathrm{~nm}$, a Cu-coating $20 \mathrm{~nm}$ thick (about 100 layers) was deposited by DCMS for $20 \mathrm{~s}$ with a content of $1 \times 10^{17} \mathrm{Cu}$ atoms $/ \mathrm{cm}^{2}$ at a rate of $5 \times 10^{15}$ atoms $/ \mathrm{cm}^{2} \cdot \mathrm{s}$.

DCMSP of $\mathrm{Cu}$ with energy pulses between 5 and $15 \mathrm{eV}$ led to faster bacterial inactivation kinetics compared to DCMS [106]. More recently, higher energies per pulse compared to DCMSP involving HIPIMS sputtering was reported by Petrov et al. [104]. HIPIMS sputtering on Cu-PES led to E. coli bacterial inactivation within $90 \mathrm{~min}$ when $\mathrm{Cu}$ was sputtered by HIPIMS pulses that were $60 \mathrm{~s}$ long at 60 A [117]. Effective bacterial inactivation was also observed in the dark. The energy and duration of the HIPIMS pulse was also limited by the heat resistance of the $\mathrm{Cu}$-target. The amount of $\mathrm{Cu}$-sputtered by HIPIMS inactivated E. coli with a Cu-loading three times lower that that compared to DCMS, leading to $E$. coli bacterial inactivation within similar times. This demonstrates substantial Cu-metal savings when using $\mathrm{Cu}$ to prepare $\mathrm{Cu}$-HIPIMS antibacterial films. A higher amount of $\mathrm{Cu}$-ions was detected by X-ray photoelectron spectroscopy (XPS) on the textile surface for HIPIMS sputtered films compared to films sputtered by DCMS and DCMSP $[64,105,106,117]$. 
2.4. Behavior of Cu-Sputtered Surfaces in the Dark and under Hospital Settings (Indoor Actinic Light), Leading to MRSA-Isolate Inactivation

Studies showing the reduction of the bacterial load on various $\mathrm{Cu}$-surfaces are of growing interest regarding indoor environments. Figure 2 shows a simplified scheme for bacterial inactivation mediated by $\mathrm{Cu} / \mathrm{CuO}$ under light irradiation. $\mathrm{Cu}$-particles are covered by $\mathrm{CuO}$ when exposed to air and present semiconductor behavior, leading to the separation of charges that induces bacterial inactivation under light. This mechanism has been accepted during the last three decades addressing the bacterial inactivation by $\mathrm{CuO}$ as shown in Figure 2 .

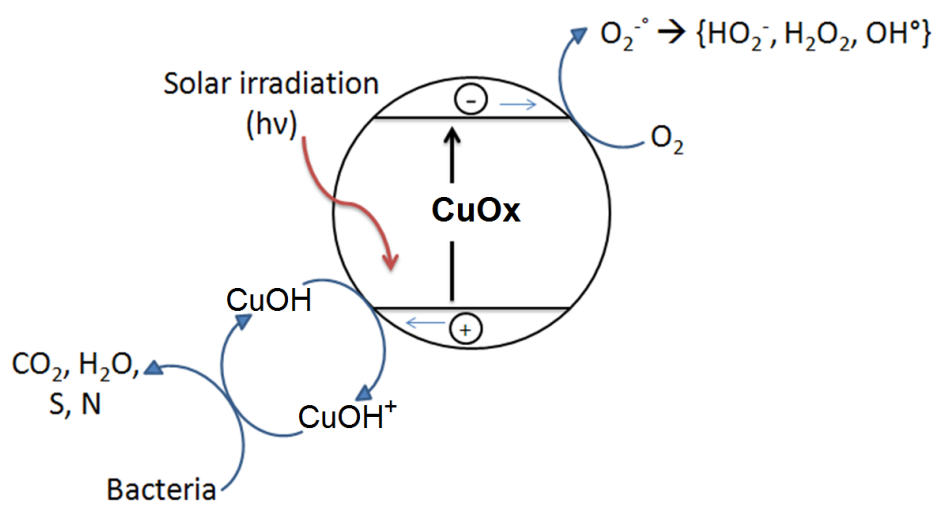

Figure 2. Conventional bacterial inactivation model on $\mathrm{PE}-\mathrm{CuO}$ films under solar light irradiation.

The inactivation of Vancomycin resistant enterococci (VRE) and MRSA isolates is important due their strong infectious effects and the fact that they can survive for months in health facilities [6-14,23-26]. The inactivation of multidrug-resistant (MDR) pathogens such as Gram-positive, Gram-negative, or fungi on Cu-polyester (Cu-PES) has been reported [132,133]. The DCMS of Cu was carried out on polyester (PES) for different times and led to uniform adhesive $\mathrm{Cu}$ nanoparticulate films. Cu-PES samples sputtered for $160 \mathrm{~s}$ were observed to induce a $6 \log _{10} \mathrm{CFU}$ loss of viability for MRSA and A. baumanni within $30 \mathrm{~min}$. The loss of bacterial viability on the Cu-PES surface for other MDR bacteria proceeded with similar times in dark/light conditions, suggesting that $\mathrm{Cu} / \mathrm{Cu}$-ions and not $\mathrm{CuO}_{\mathrm{x}}$ led to the observed bacterial loss of viability. The use of gloves, gowns, and masks, as well as patient isolation, have limited the spread of infections, but on their own are not able to avoid the transmission of HCAIs [134,135].

Copper is required by eukaryotic and prokaryotic cells at low concentrations as cofactors in metal-proteins and enzymes, but at high concentrations, $\mathrm{Cu}$-(II) has a toxic effect. Cu intervenes by substituting essential ions and blocking the functional groups of proteins, inactivating enzymes, which produces highly oxidative free radicals such as $\mathrm{HO}^{\bullet}, \mathrm{HO}_{2}{ }^{\bullet}$, and $\mathrm{O}_{2}{ }^{-}$which damages the membrane integrity [30-40]. A number of studies have demonstrated the efficient killing of bacteria/fungi on Cu-surfaces and Cu-alloys, both in vitro and in a clinical setting; Espirito Santo et al. [136,137], Grass et al. [138], and Casey et al. [139]. These studies show that Cu-surfaces rapidly and efficiently kill bacteria, in some cases accumulating $\mathrm{Cu}$-ions on the cell wall membranes. This step seems to be followed by $\mathrm{Cu}$-uptake, leading to loss of integrity of the cell wall and $\mathrm{Cu}$-translocation. These studies also report that $\mathrm{Cu} / \mathrm{Cu}$-ions are effective against a wide variety of microbes, but the mode of intervention of the $\mathrm{Cu} / \mathrm{Cu}$-ions and the inactivation mechanism still remains controversial. Experimental evidence for reactive oxidative stress (ROS) on the cytoplasm of $\mathrm{Cu}$-stressed yeast has been presented. New biomaterials consider additives that interfere with biofilm formation, adhesive properties, and involve a microstructure driving the antibacterial action [13]. Testing the antibacterial action of many metals on $\mathrm{TiO}_{2}$ films, the metal-ion toxicity of $\mathrm{Cu}$-ions was found to be much higher compared to Ag-, $\mathrm{Zn-}, \mathrm{Co}-, \mathrm{Al}-$, and $\mathrm{Hg}$-ions. The in vitro growth inhibition revealed 
the higher activity of $\mathrm{Cu}$-ions as an antibacterial and bio-tolerant additive in ppb amounts [140]. Due to the fact that many bacteria grow easily on polyethylene that is widely used to wrap all kinds of objects: pharmaceuticals, perishables, and surgical materials by $\mathrm{Cu}$-polyethylene (Cu-PE) thin polymeric films, our laboratory decided to sputter $\mathrm{Cu}$ on PE by DCMS and test its bacterial inactivation performance [141]. Cu-coatings of $25 \mathrm{~nm}$ thickness were sputtered at $60 \mathrm{~W}$ and deposited $0.16 \%$ weight $\mathrm{Cu}$ /weight $\mathrm{PE}$, leading to bacterial inactivation under low intensity simulated sunlight $(20 \%$ the solar irradiation reaching the equator at noon presenting $100 \mathrm{~mW} / \mathrm{cm}^{2}$ ). These films were also able to induce complete bacterial inactivation in the dark within $90 \mathrm{~min}$ and at a faster rate within $15 \mathrm{~min}$ under low intensity sunlight. Repetitive photo-induced bacterial inactivation was observed on the $\mathrm{CuO}_{\mathrm{x}}-\mathrm{PE}$. The $\mathrm{Cu}$ released in the ppb-range during the catalyst recycling was determined by inductively coupled plasma mass-spectrometry (ICP-MS). An increase in the applied light intensity accelerated the bacterial inactivation kinetics, providing evidence for the semiconductor behavior of the $\mathrm{CuO}_{x}$ film. Using $\mathrm{X}$-ray photoelectron spectroscopy (XPS), the binding energy (BE) of the Cu-species was observed to shift after the bacterial inactivation cycle, providing evidence for redox processes during bacterial inactivation.

The use of intravenous catheters (IVCs) in patients who require vascular access is often associated with the development of potentially severe infections, including bloodstream infections (BSI), metastatic abscesses, and infective endocarditis [142,143]. Catheters are commonly colonized by microorganisms present on the skin at the time of intravascular insertion [144]. The infections caused by staphylococci, such as Staphylococcus aureus, are problematic in the case of methicillin-resistant S. aureus (MRSA) [145]. Polyurethane catheters currently used in Swiss hospitals do not generally have an infection during the first day, but are prone to infections when used for longer hospital periods [23-25,100,112,133,135]. Catheters (being 3D-objects) were sputtered by Ag-Cu and the substrate/sputtered film was maintained under a negative bias of 100-200 V. The Ag/Cu-coatings sputtered led to a faster bacterial inactivation compared to either $\mathrm{Ag}$ or $\mathrm{Cu}$ by themselves. The layers presented a thickness of $\sim 30 \pm 3 \mathrm{~nm}$ (150 layers) on the catheters. The antibacterial coatings were investigated for their efficacy in preventing MRSA infections in vitro and in vivo [145]. $\mathrm{Ag}$ and $\mathrm{Cu}$ were sputtered (67\%/33\% ratio) externally on polyurethane catheters by DCMS. In vitro, Ag/Cu-coated and uncoated catheters were immersed for $18 \mathrm{~h}$ at $4{ }^{\circ} \mathrm{C}$ in PBS or rat plasma and exposed to $10^{4}-10^{8} \mathrm{CFU}$ of MRSA ATCC 43300 for $90 \mathrm{~min}$ at $37^{\circ} \mathrm{C}$. In vivo, $\mathrm{Ag} / \mathrm{Cu}$-coated and uncoated catheters were placed in the jugular vein of rats. Nearby, MRSA $\left(10^{7} \mathrm{CFU}\right)$ was inoculated in the tail vein. Catheters were removed $48 \mathrm{~h}$ later and cultured. In vitro, $\mathrm{Ag} / \mathrm{Cu}$-coated catheters that were pre-incubated in phosphate buffered saline (PBS, a biological media used routinely in bacterial testing) and exposed to $10^{4}-10^{7} \mathrm{CFU}$, prevented the adherence of MRSA ( $0 \%-12 \%$ colonization) compared to the uncoated catheters $(50 \%-100 \%$ colonization; $p<0.005)$. When pre-incubated in rat plasma, $\mathrm{Ag} / \mathrm{Cu}$-coated catheters retained their activity $(0 \%-20 \%$ colonization) while the colonization of uncoated catheters increased $(83 \%-100 \% ; p<0.005)$. Ag/Cu-coating protection decreased with $10^{8} \mathrm{CFU}$ in both PBS and plasma ( $50 \%-100 \%$ colonization). For the in vivo experiments, $\mathrm{Ag} / \mathrm{Cu}$-coated catheters reduced the incidence of catheter infection compared to uncoated catheters (79\% vs. 57\%, respectively) and bacteraemia ( $68 \%$ vs. $31 \%$, respectively; $p<0.05)$. Scanning electron microscopy (SEM) of explanted catheters suggests that the $\mathrm{Ag} / \mathrm{Cu}$ catheters formed a dense fibrin sheath over their surface in vivo, hindering the access of $\mathrm{Ag} / \mathrm{Cu}$ to the infecting staphylococci. Their activity might be improved by limiting plasma protein adsorption on their surface. The Ag/Cu-coating of catheters completely prevented catheter infection by MRSA in vitro.

Due to the interest of the subject and the recent advances in the Cu-inactivation of pathogens, several studies have addressed this area and have reported incipient results on $\mathrm{Cu}$-mediated disinfection processes [146-154].

\subsection{Photocatalytic/Catalytic Bactericidal Effects on E. coli and $M R S A$ by $\mathrm{TiO}_{2} / \mathrm{Cu}$ Thin Films}

In the last decade, $\mathrm{Cu}$ has been widely reported to increase the bactericidal activity of $\mathrm{TiO}_{2}[13,22,42,43,56,64,94,112-115,132-142,153]$. This section presents some relevant developments 
(and references) of work regarding bacterial inactivation mediated by $\mathrm{TiO}_{2} / \mathrm{Cu}$ powders and $\mathrm{TiO}_{2} / \mathrm{Cu}$ surfaces by catalysis and photocatalysis. Doping/decorating $\mathrm{TiO}_{2}$ by $\mathrm{Cu} / \mathrm{CuO}_{\mathrm{x}}$ enhances the visible light absorption of $\mathrm{TiO}_{2}$ and it has also been suggested to enhance the charge separation. The speciation of $\mathrm{Cu}$ on the $\mathrm{TiO}_{2}$ surface and the mechanism of interfacial charge transfer (IFCT) between $\mathrm{TiO}_{2}$ and $\mathrm{Cu}$ remains a controversial matter.

Inactivation of bacteria under UV and visible light on $\mathrm{TiO}_{2} / \mathrm{Cu}$ has been reported by the group of Applied Chemistry, University of Tokyo in the seminal references [155-158]. Hashimoto's laboratory has published studies on the preparation of $\mathrm{TiO}_{2} / \mathrm{Cu}$ nanoparticles by sol-gel methods and have evaluated their performance under UV and visible light. Under weak UV-indoor lighting, they demonstrated a notable activity increase of bacterial inactivation by the $\mathrm{TiO}_{2} / \mathrm{Cu}$ films $(40 \pm 4 \mathrm{~nm})$ with respect to $\mathrm{TiO}_{2}$-films. The observed effect was ascribed to the ROS generated under band-gap irradiation, which first attacked/damaged the LPS E. coli outer membrane, followed by the effective uptake of the $\mathrm{Cu}$-ions on the membrane cell wall. This in turn allows for the translocation of $\mathrm{Cu}$-ions into the bacteria cytoplasm, leading to cell lysis. Subsequently, this group showed the effect of sunlight on $\mathrm{Cu}$ grafted $\mathrm{WO}_{3}-\mathrm{TiO}_{2}$ powders, which increased the bacterial inactivation kinetics under light due the $\mathrm{WO}_{3}$ interfacial charge transfer (IFCT) to $\mathrm{TiO}_{2}$ [157]. The bacterial inactivation of bacteriophages and viruses on $\mathrm{TiO}_{2} / \mathrm{Cu}$ was recently reported [158] by the same group on foam samples used in air cleaners. The results show that the pathogen count in the polluted air could be decreased using the approach suggested in this study, improving the performance with suitable $\mathrm{TiO}_{2} / \mathrm{Cu}$ containing foams.

Physical vapor deposition (PVD) and chemical vapor deposition (CVD) have been widely used as mentioned in references [91-94] to coat glass, silicon, polymers, and steel with $\mathrm{TiO}_{2}$ and other metals and metal/oxides. Work along these lines, coating $\mathrm{TiO}_{2} / \mathrm{Cu}$ on silica by $\mathrm{CVD}$ at $500{ }^{\circ} \mathrm{C}$ has been reported [159]. Recently, the preparation of uniform, adhesive, robust antibacterial coatings of textiles and thin polymers such as polyethylene (PE), polyurethane (PU), and textiles resisting much lower temperatures up to $160^{\circ} \mathrm{C}$, has employed sputtering methods working below this temperature that is applied for short times, and has gained attention for the applications of 2D/3D sputtered materials in health facilities, garments, and many artifacts used in hospital facilities [23-26]. Pioneering work in this area has been carried out for two decades by P. Kelly, who has studied in a detailed and comprehensive way the sputtering configuration and the antibacterial performance of the sputtered surfaces. In conjunction with J. Veran, they have reported work that contributes to the understanding of the film microstructure and its effect on the abatement of pathogens [160-162].

Recently S. Pillai [163] has carried out work on the ability of $\mathrm{TiO}_{2} / \mathrm{Cu}$ nanoparticulates co-doped with fluorine (F) to abate Staphylococcus aureus (MRSA) under visible light. Fluorine introduced visible light absorption in $\mathrm{TiO}_{2}$, inducing $\mathrm{Ti}^{3+}$ and leading to O-vacancies and precluding $\mathrm{e}^{-} / \mathrm{h}^{+}$ recombination in $\mathrm{TiO}_{2}$. A sol-gel preparation using aqueous titanyl acetate and titanyl trifluoroacetate with added Cu-nitrate was prepared according to US patent 9,210,934 [164]. The sol was then deposited on glass plates by dip-coating, and after drying was heated to $550{ }^{\circ} \mathrm{C}$. In the initial anatase network, the $\mathrm{O}$ sites were substituted partially by $\mathrm{F}$ and the $\mathrm{Ti}$ by $\mathrm{Cu}[43,56]$. The addition of $\mathrm{F}$ and $\mathrm{Cu}$ significantly improved the inactivation of MRSA under visible light irradiation, similar to that available in hospital facilities. When $\mathrm{TiO}_{2}$ was doped only with $\mathrm{F}$, the photocatalytic activity was observed to be below that registered for $\mathrm{TiO}_{2} / \mathrm{F} / \mathrm{Cu}$, illustrating the synergistic effect of the combined doping of $\mathrm{F}$ and $\mathrm{Cu}$. $\mathrm{Cu}$-doping improved the bacterial inactivation on $\mathrm{TiO}_{2}$, but $\mathrm{TiO}_{2}-\mathrm{F}$ was ineffective for MRSA inactivation under dark conditions.

\subsection{Current Work on $\mathrm{TiO}_{2} / C u$ Sputtered Surfaces by DCMS, DCMSP, and HIPIMS, Bactericidal Effects and Thin Film Properties}

In the sputtering chamber, the $\mathrm{Cu}$ - and Ti-targets shown in Figure 3 were bombarded by Ar-ions generated in the glow discharge plasma at a plasma working pressure was $0.4 \mathrm{~Pa}$. The distance between the targets and the substrate was $\sim 10 \mathrm{~cm}$ and the diameter of the $99.9 \% \mathrm{Cu}$ and Ti targets was $5 \mathrm{~cm}$. The deposition currents generally used for DCMS were $50-300 \mathrm{~mA}$ and a bias voltage of 
100-300 V was applied. Under these conditions, the $\mathrm{Cu}$ and Ti-ions were estimated to penetrate up to about $20 \mathrm{~nm}$ on textile substrates [105-107,117].

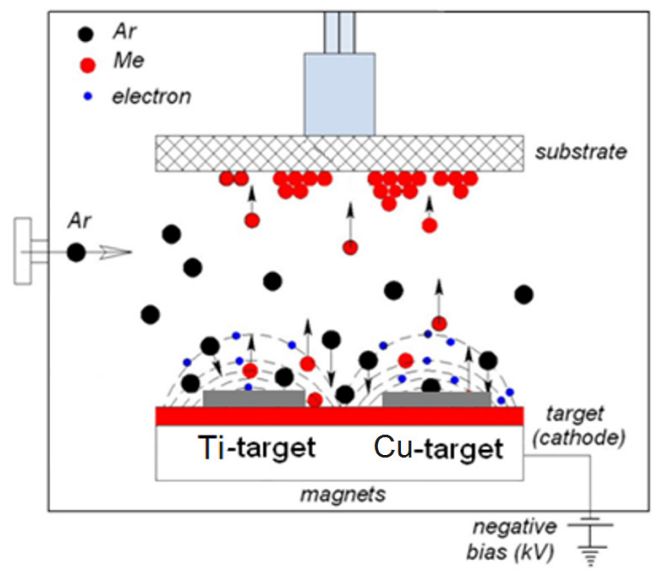

Figure 3. Schematic representation of the two target-sputtering unit used to deposit inactivating agents on the substrates.

The thin uniform $\mathrm{TiO}_{2} / \mathrm{Cu}$ films on cotton, about $78 \mathrm{~nm}$ thick, were sputtered in the unit shown below. The most suitable films leading to bacterial inactivation consisted of Ti sputtered for $10 \mathrm{~min}$, sequentially sputtered by $\mathrm{Cu}$ for $40 \mathrm{~s}$ at $300 \mathrm{~mA}$, under a partial pressure of $\mathrm{O}_{2}$ of $0.08 \mathrm{~Pa}$ and a partial pressure of Ar of $0.4 \mathrm{~Pa}$. This Cu-doped sample inactivated E. coli within about $30 \mathrm{~min}$ in dark conditions.

Bacterial inactivation was completed within 5-6 min under low intensity actinic light $>400 \mathrm{~nm}$, providing evidence for: (a) the synergic interaction between $\mathrm{Cu}$ and $\mathrm{TiO}_{2}$ and (b) the interfacial charge transfer (IFCT) occurring between $\mathrm{TiO}_{2}$ and $\mathrm{Cu}$ under band-gap irradiation [165]. The bacterial inactivation involved redox catalysis. This is the variation of the $\mathrm{Cu}$-oxidation state during the bacterial process due to the contact of the bacteria with the topmost $\mathrm{Cu} / \mathrm{CuO}$ layers in the $\mathrm{TiO}_{2} / \mathrm{Cu}$ sample. The evidence for this occurrence was obtained by X-ray photoelectron spectroscopy (XPS) for variations $>0.2 \mathrm{ev}$ in the spectrograms for $\mathrm{Cu}, \mathrm{O}$, and $\mathrm{C}$ observed for samples at time zero and for samples after the 5-6 min disinfection period induced under indoor visible light irradiation.

The diffuse reflectance spectra (DRS) of the sputtered $\mathrm{TiO}_{2} / \mathrm{Cu}$ sample in Figure 4 shows that $\mathrm{Cu}$ does not substitute $\mathrm{Ti}^{4+}$ in the $\mathrm{TiO}_{2}$ crystal lattice. Ti and $\mathrm{Cu}$-ions were released in ppb amounts during bacterial disinfection, providing evidence that the bacterial inactivation involves predominantly an oligodynamic effect $[76,118]$. The small amounts of $\mathrm{Cu}$ released during disinfection electrostatically bind to the $\mathrm{S}-$ and $\mathrm{N}$ - and $\mathrm{COO}$ - negative groups of the bacterial cell wall before translocating onto the bacterial cytoplasm. This mechanism was originally suggested by the Tokyo University photocatalysis laboratory [155-158]. Figure 4 shows the $\mathrm{Cu}$ released during the disinfection cycles by a $\mathrm{TiO}_{2} / \mathrm{Cu}$ (10 $\mathrm{min} / 40 \mathrm{~s})$ sputtered sample irradiated by actinic light $\left(4 \mathrm{~mW} / \mathrm{cm}^{2}\right)$. After each cycle, the samples were washed thoroughly before starting the next repetitive cycle. After the eighth cycle, Figure 4 shows $\mathrm{Cu}$ was released at $\mathrm{ppb}$ levels $<8 \mathrm{ppb}$. These $\mathrm{Cu}$-levels are not considered cytotoxic to mammalian cells $[150,166]$.

Figure 5 shows a concomitant lower release of $8 \mathrm{ppb}$ Ti-ions during bacterial disinfection, which dropped to about $4 \mathrm{ppb}$ after the eighth cycle. This lower Ti-ion release is consistent with the very high stability reported for $\mathrm{TiO}_{2}$ up to $\mathrm{pH} \sim 13$.

$\mathrm{TiO}_{2} / \mathrm{Cu}$ cotton samples increased the $E$. coli inactivation kinetics with the increase of the applied light intensity [166]. Therefore, the predominant effect leading to bacterial inactivation seems to be due to the photo-generated charges either by: (a) the $\mathrm{TiO}_{2} ;(\mathrm{b})$ the intermetallic $\mathrm{TiO}_{2} / \mathrm{Cu}$ and $\mathrm{TiO}_{2}-\mathrm{Cu}$ phases; and finally (c) the $\mathrm{CuO}$. 


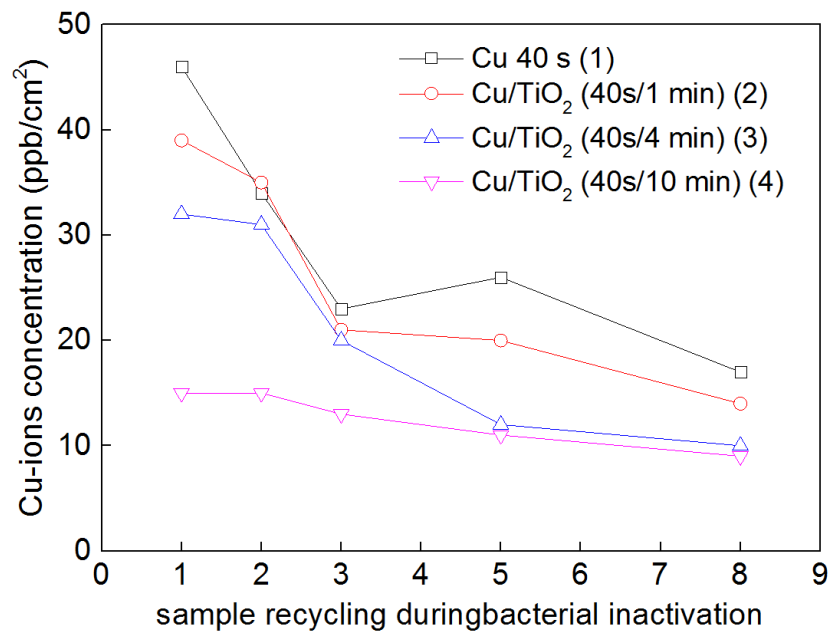

Figure 4. $\mathrm{Cu}$ ions release from diverse $\mathrm{Cu}$-cotton and $\mathrm{TiO}_{2} / \mathrm{Cu}$-cotton sputtered films as a function of catalyst cycling up to the 8 th cycle.

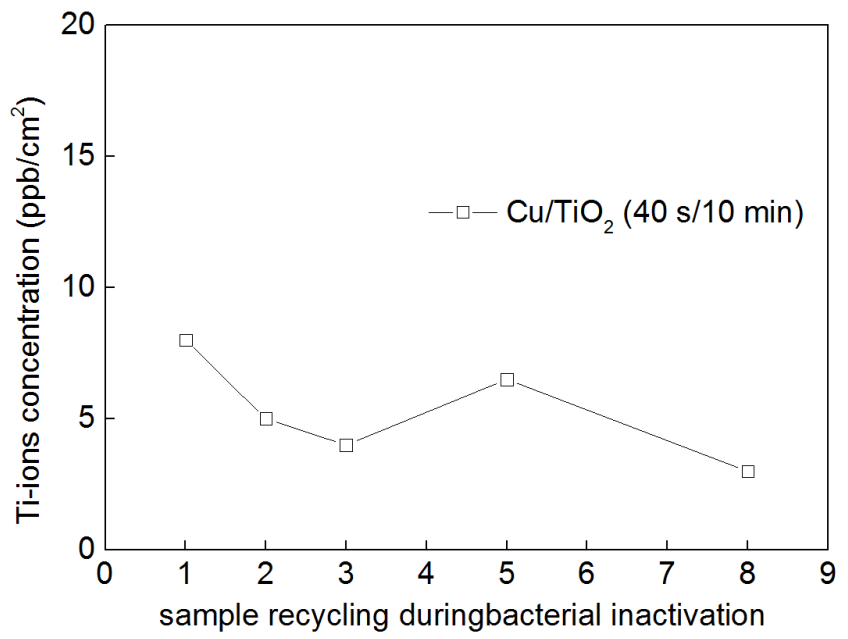

Figure 5. Ti-ions release from a diverse $\mathrm{TiO}_{2} / \mathrm{Cu}(10 \mathrm{~min} / 40 \mathrm{~s})$ cotton sputtered sample as a function of catalyst cycling up to the eighth cycle.

\section{7. $\mathrm{TiO}_{2}-\mathrm{Cu}$ Films by HIPIMS: Comparison of the Bacterial Inactivation Performance with} DCMS/DCMSP-Films

In a recent study, we reported that sputtering by HIPIMS on polyester (PES) showed that thinner $\mathrm{TiO}_{2}$-Cu HIPIMS sputtered films $(\sim 40 \mathrm{~nm})$ induced bacterial inactivation of E. coli within 9-12 min compared to bacterial inactivation on thicker $\mathrm{TiO}_{2} / \mathrm{Cu}$ sequentially sputtered by DCMS/DCMSP (600 nm thick) [125]. To carry out the HIPIMS co-sputtering, the target used was $60 \% \mathrm{Ti} / 40 \% \mathrm{Cu}$ by weight and the pulse used $5 \mathrm{~A}$ and $350 \mathrm{~V}$ with a power of $1750 \mathrm{~W}$ during the 100 microsecond pulses. DCMS of $\mathrm{TiO}_{2}(0.3 \mathrm{~A})$ was followed by Cu-sputtering by DCMSP $(0.3 \mathrm{~A} / 622 \mathrm{~V})$ with pulses of 10 microseconds at an average power of $187 \mathrm{~W} /$ pulse. Figure 6 presents the loss of viability kinetics vs. thickness for the DCMS/DCMSP and HIPIMS $\mathrm{TiO}_{2}-\mathrm{Cu}$ sputtered films. Figure 6 shows that the much thinner $\mathrm{TiO}_{2}-\mathrm{Cu}$ layer sputtered by HIPIMS was required for complete bacterial inactivation, compared to that by DCMS/DCMSP.

Coated polyester (PES) films sputtered by DCMS/DCMSP in Figure 6 proceeded at much lower energies compared to HIPIMS films. DCMS prepared $\mathrm{TiO}_{2} / \mathrm{Cu}$ films in Figure 6 induced bacterial inactivation by films $\sim 15$ times thicker compared to the HIPIMS prepared films $[107,108]$. In Figure 6 , the HIPIMS films have the following characteristics: $40 \mathrm{~nm}$ thickness, $5 \pm 2 \mathrm{~nm}$ size of the $\mathrm{TiO}_{2} / \mathrm{Cu}$ 
nanoparticles, and the $\mathrm{TiO}_{2}$ anatase phase as determined by XRD. The DCMS/DCMSP films presented a thickness of $600 \mathrm{~nm}, 20 \pm 5 \mathrm{~nm} \mathrm{Cu} / \mathrm{TiO}_{2}$ nanoparticles, and the $\mathrm{TiO}_{2}$ anatase phase was also found.

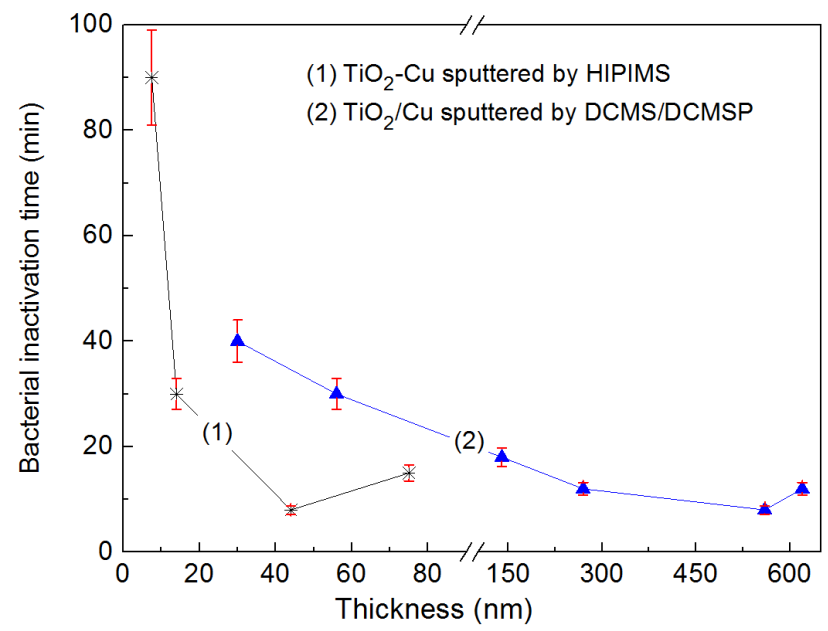

Figure 6. Bacterial inactivation time vs. nominal thicknesses for $\mathrm{TiO}_{2} / \mathrm{Cu}$ sputtered by High Power Impulse Magnetron Sputtering (HIPIMS) films and $\mathrm{TiO}_{2} / \mathrm{Cu}$ sputtered by Direct Current Magnetron Sputtering or Pulsed Direct Current Magnetron Sputtering (DCMS/DCMSP) irradiated under Osram Lumilux $18 \mathrm{~W} / 827$ actinic lamp $\left(4 \mathrm{~mW} / \mathrm{cm}^{2}\right)$. Error bars: standard deviation $(n=10 \%)$.

In the seminal work cited in reference [107], Figure 7 shows that the optimized $\mathrm{Cu} / \mathrm{TiO}_{2}$ coating inactivates bacteria within $10 \mathrm{~min}$. The bacterial inactivation depends on the film thickness in the following way: concomitant to the variation of the film thickness (increase or decrease), the roughness of the layers will also vary, presenting different values for the average roughness $R_{\mathrm{a}}$. A higher roughness shows the existence of peaks more closely packed on the substrate surface. An optimal value for the roughness is not necessarily related to thicker coatings but is a function of many surface properties developed on the sputtered layers. This is why the roughness has to be determined for each individual coating, generally by AFM, for metal/oxides or composite microstructures.

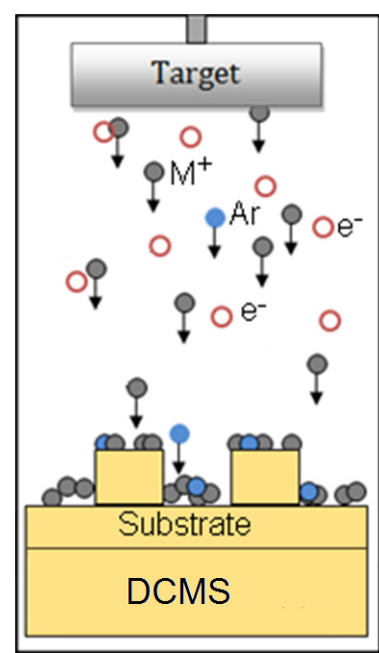

(a)

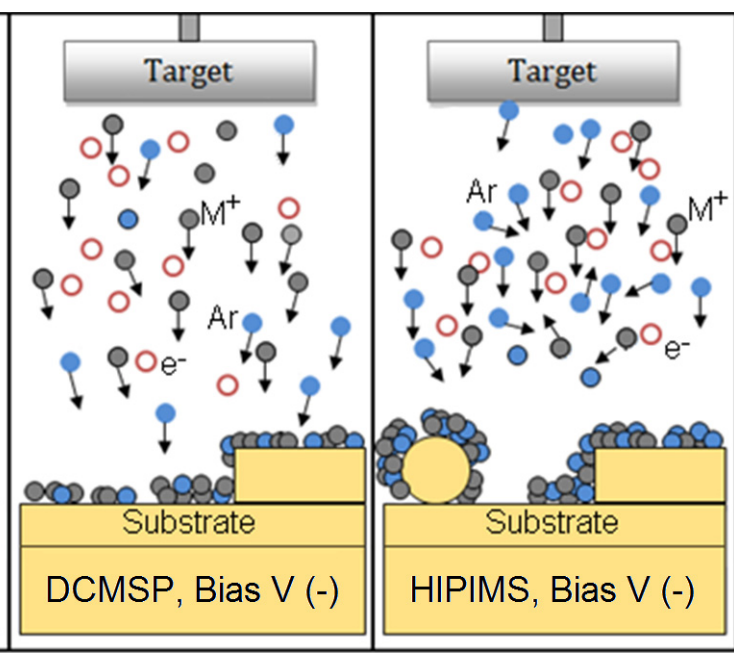

(c)

Figure 7. Schematics of the (a) DCMS, (b) DCMSP and (c) HIPIMS sputtering of metal-ions $\left(\mathrm{M}^{+}\right)$on 3-D surfaces. 
In Figure 7, the left-hand side presents a scheme for the DCMS sputtering proceeding with a low ionization of the $\mathrm{Cu}$-ions of $\sim 1 \%-5 \%$ [126]. The DCMSP of $\mathrm{Cu}$ is shown in the middle section of Figure 7 , attaining Cu-ionization of $5 \%-10 \%$ with an electronic density of $\sim 10^{15-16} \mathrm{e}^{-} / \mathrm{m}^{3}[107,108,120]$. This is well above the Cu-ionization percentages attained by DCMS $[107,120-122,125,126]$. In the case of the DCMS/DCMSP Cu/ $\mathrm{TiO}_{2}$ films, the fastest bacterial inactivation was attained by sputtering $\mathrm{TiO}_{2}$ by DCMS for $10 \mathrm{~min}$ followed by Cu-DCMSP for $60 \mathrm{~s}$. The right-hand section of Figure 7 shows the density of the species attained by HIPIMS that is able to ionize $\mathrm{Cu}$ up to $70 \%$ with an electronic density in the plasma of $\sim 10^{18-19} \mathrm{e}^{-} / \mathrm{m}^{3}$ [101]. HIPIMS sputtering for $150 \mathrm{~s}$, applying a current of $5 \mathrm{~A}$ on a mixed target $\mathrm{Cu} / \mathrm{TiO}_{2}\left(60 \% \mathrm{TiO}_{2}\right.$ and $\left.40 \% \mathrm{Cu}\right)$, led to a film with a composition of $0.08 \% \mathrm{CuO}$ and $0.44 \% \mathrm{TiO}_{2}$ by weight. The higher energy HIPIMS increases the amount of ionized $\mathrm{Cu}$-ions in the reaction:

$$
\mathrm{Cu}^{0} \rightarrow \mathrm{Cu}^{+} / \mathrm{Cu}^{2+}
$$

$\mathrm{Cu}^{0}$ in Equation (24) refers to $\mathrm{Cu}$-metal.

HIPIMS sputtered $\mathrm{TiO}_{2}$ for $10 \mathrm{~min}$ and $\mathrm{Cu}$ for $60 \mathrm{~s}$ on PES inactivated E. coli under actinic light as shown in Figure 6. Figure 8 shows the release of $\mathrm{Cu}$-ions that are inactivating E. coli from the HIPIMS sputtered $\mathrm{TiO}_{2}-\mathrm{Cu} \mathrm{PES}$ as a function of catalyst recycling. Inductively coupled plasma spectrometry (ICP-MS) was used to determine the $\mathrm{Cu}$, since it is a sensitive analytical technique. A Finnigan ${ }^{\mathrm{TM}}$ ICPS was used and was equipped with a double focusing reverse geometry mass spectrometer with a resolution of $1.2 \times 10^{5} \mathrm{cps} / \mathrm{ppb}$, and a detection limit of $0.2 \mathrm{ng} / \mathrm{L}$. Samples $1 \mathrm{~cm}^{2}$ were placed in Eppendorf tubes containing a $1 \mathrm{~mL}$ solution $(\mathrm{NaCl} / \mathrm{KCl})$. The solutions were then diluted 10 times to reach the volume and/or dilution necessary for the ICP-MS analyses. After the eighth recycling, the release of $\mathrm{Cu}$ was $\sim 8 \mathrm{ppb} / \mathrm{cm}^{2}$. This value is lower than the $\mathrm{Cu}$ release from the $\mathrm{Cu}$-sputtered PES samples of $\sim 18 \mathrm{ppb} \mathrm{Cu} / \mathrm{cm}^{2}$ after the eighth cycle. This shows the stabilizing/protective/adhesive effect of $\mathrm{TiO}_{2}$ on the $\mathrm{Cu}$. Release of $\mathrm{Cu}$ at the ppb levels shown in Figure 8 are not considered to be cytotoxic to mammalian cells. The E. coli disinfection cycles shown in Figure 8 may well proceed through an oligodynamic effect. This toxic effect of metals such as $\mathrm{Cu}$ at extremely low concentrations leads to the inactivation of bacteria, fungi, and viruses $[76,118,150]$. Please make sure that the intended meaning is retained.

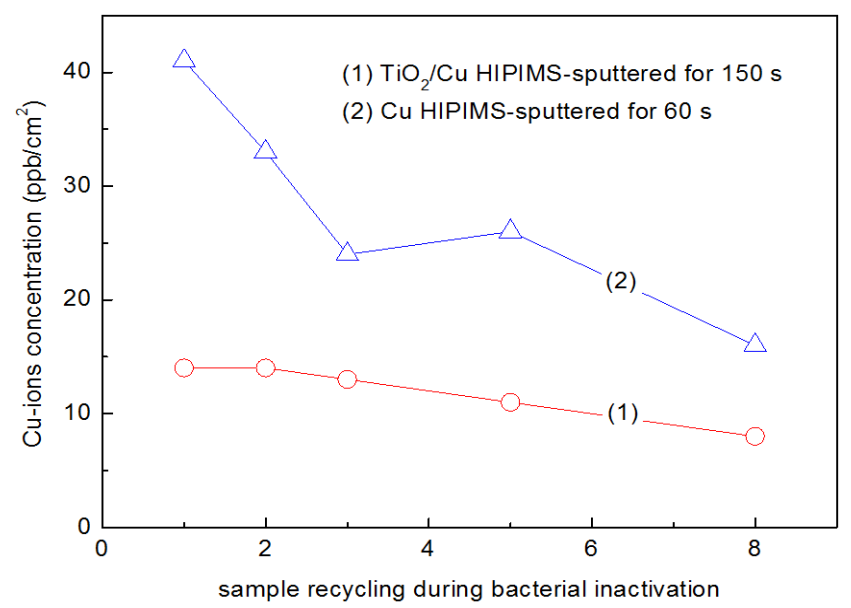

Figure 8. The concentration of ions eluted into solution determined by Inductively Coupled Plasma Mass Spectrometry (ICP-MS) up to the eighth recycling of $\mathrm{TiO}_{2} / \mathrm{Cu}$ prepared by High Power Impulse Magnetron Sputtering (HIPIMS) sputtered samples, inactivating E. coli under actinic light.

HIPIMS sputtered for $30 \mathrm{~s}$ show $\mathrm{Cu}$ nanoparticles between 8 and $15 \mathrm{~nm}$. The $\mathrm{TiO}_{2}$ samples sputtered for $150 \mathrm{~s}$ present sizes between 8 and $12 \mathrm{~nm}$, and the $\mathrm{TiO}_{2}-\mathrm{Cu}$ samples sputtered for $150 \mathrm{~s}$ presented particles $5-10 \mathrm{~nm}$. $\mathrm{TiO}_{2}$ has been suggested to bind, disperse, and stabilize the $\mathrm{Cu}$-clusters on the PES surfaces. The distribution of $\mathrm{TiO}_{2}$ and $\mathrm{Cu}$ nanoparticles on the PES in Figure 9 was found 
to be uniform, with no cracks present. Figure 10a presents the contrasted high angular annular dark field (HAADF) $\mathrm{TiO}_{2} / \mathrm{Cu}$ microscopy image, showing the $\mathrm{Cu}$ nanoparticles to be immiscible with Ti. Figure $10 \mathrm{~b}$ shows the mapping/distribution of the $\mathrm{Cu}$, $\mathrm{Ti}$, and $\mathrm{O}$ on PES.
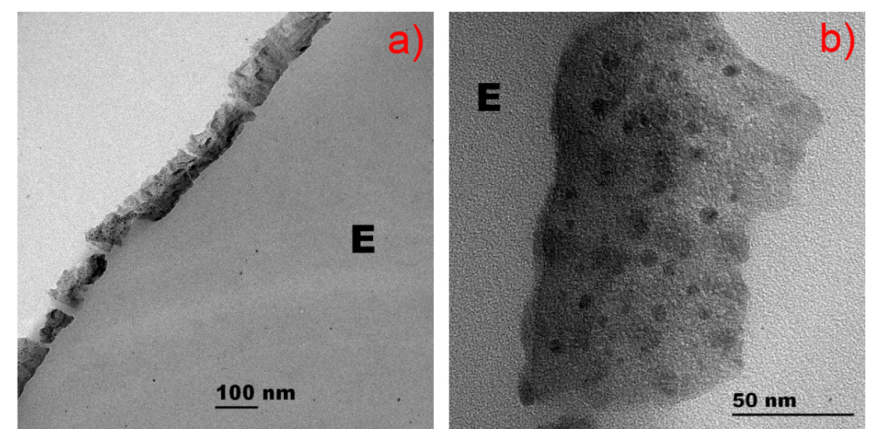

Figure 9. Transmission electron microscopy (TEM) of: (a) Cu sputtered for $150 \mathrm{~s}$ by HIPIMS on polyester; (b) $\mathrm{Cu}-\mathrm{TiO}_{2}$ sputtered for $150 \mathrm{~s}$ by HIPIMS on polyester.

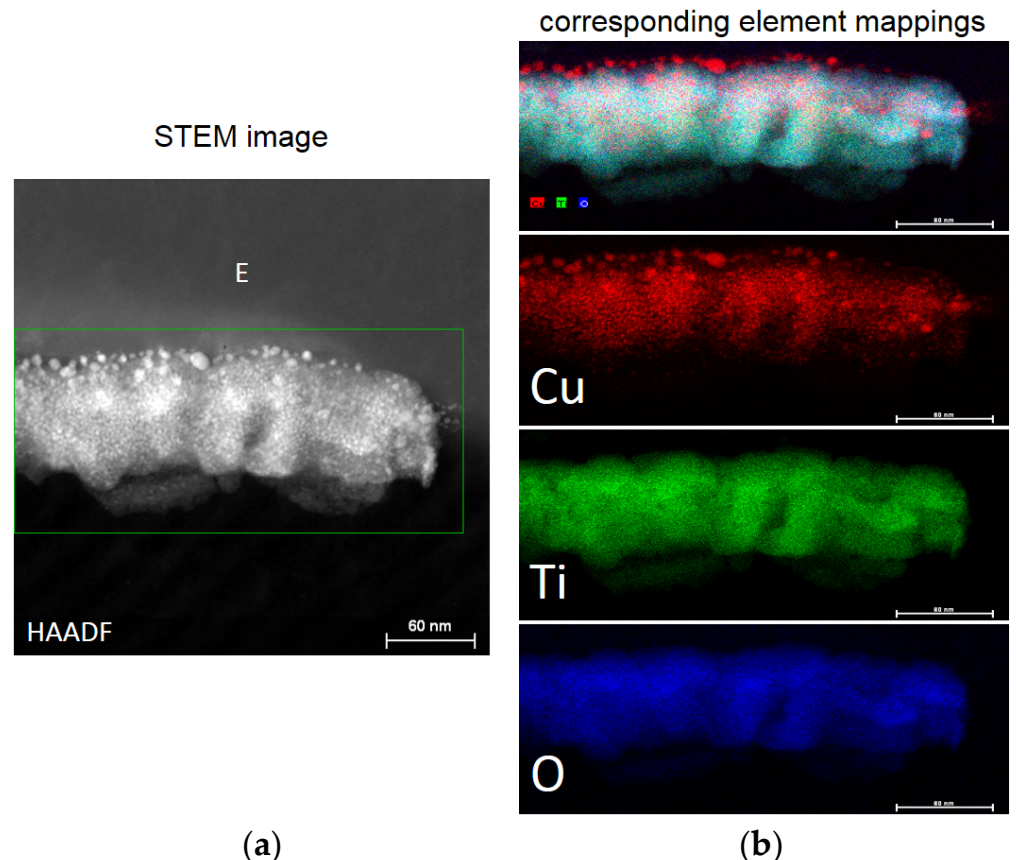

Figure 10. (a) High-Angle Annular Dark-Field imaging (HAADF) images of $\mathrm{Cu}-\mathrm{TiO}_{2} \mathrm{HIPIMS}$ sputtered for $150 \mathrm{~s}$ showing the complete sample and $(\mathbf{b})$ the mapping of $\mathrm{Cu}, \mathrm{Ti}$, and $\mathrm{O}$ by $\mathrm{Z}$-contrast imaging.

Transmission electron microscopy was carried out in a FEI Tecnai TEM-STEM Osiris $(200 \mathrm{kV}$, EDX: FEI Super-X; software: Esprit analysis, Bruker Nano), and was used to measure the grain size of the $\mathrm{TiO}_{2} / \mathrm{Cu}$ films. To carry out this observation, textiles were embedded in epoxy resin 45359 Fluka (designated as E in Figures 9 and 10) and the fabrics were cross-sectioned with an ultramicrotome at a knife angle of $35^{\circ}$. These images (Z-contrast images) were obtained by collecting the scattered electrons passing through the objective provided with an annular dark-field detector.

Due to the small size found for the $\mathrm{CuO} / \mathrm{Cu}$ nanoparticles as reported in Figure 9, these $\mathrm{CuO} / \mathrm{Cu}$ nanoparticles are not able to penetrate into the bacteria core through the cell wall porins with diameters of 1-1.3 nm [109]. However, Cu-ions are able to diffuse through the cell wall porins leading to cytoplasm/DNA damage and finally to the loss of bacterial viability. 


\subsection{Interfacial Charge Transfer (IFCT) Suggested on $\mathrm{TiO}_{2}$-Cu Films Leading to Gram-Negative and Gram-Positive Bacterial Inactivation}

Figure 11 shows the interfacial charge transfer between $\mathrm{TiO}_{2}$ and $\mathrm{Cu}$ under simulated solar irradiation. In the $\mathrm{TiO}_{2}$ semiconductor, the irradiation with solar simulated light in the cavity of the solar simulator has been suggested to transfer $\mathrm{e}^{-}$and $\mathrm{h}^{+}$from $\mathrm{TiO}_{2}$ to $\mathrm{CuO}$. Charge transfer from ad-atoms to $\mathrm{TiO}_{2}$ under light has been investigated for the last three decades [167]. The potential energy levels of the $\mathrm{TiO}_{2} \mathrm{cb}$ and $\mathrm{TiO}_{2}$ vb lie above the $\mathrm{CuOcb}$ and $\mathrm{CuOvb}$ levels, as shown in Figure 11 . The partial recombination of $\mathrm{e}^{-} / \mathrm{h}^{+}$in $\mathrm{TiO}_{2}$ would be hindered by the charge injection into $\mathrm{CuO}$. The interfacial charge transfer (IFCT) to $\mathrm{TiO}_{2}$ from the $\mathrm{CuOvb}$ at $+1.4 \mathrm{eV}$ to the $\mathrm{TiO}_{2} \mathrm{vb}$ at $+2.5 \mathrm{eV}$ vs. $\mathrm{SCE}, \mathrm{pH}$, proceeds with considerable driving force due to the large difference between these two vb levels. This model for the charge transfer between $\mathrm{TiO}_{2}$ and $\mathrm{CuO}$ under solar light (UV-Vis) has been suggested by Hashimoto $[107,156,168]$ and is presented in Figure 5. The E. coli inactivation times proceeding within $10 \mathrm{~min}$ is shown in Figure 11. These $\mathrm{TiO}_{2} \mathrm{vb}$ holes react with the surface - $\mathrm{OH}$ groups of the $\mathrm{TiO}_{2}$ releasing $\mathrm{OH}$-radicals. The $\mathrm{CuO}$ nanoparticles on the $\mathrm{TiO}_{2}$ can be reduced to $\mathrm{Cu}_{2} \mathrm{O}$ by the charges generated in the $\mathrm{TiO}_{2}$ under light and can later re-oxidize to $\mathrm{CuO}$, as shown in Figure 11.

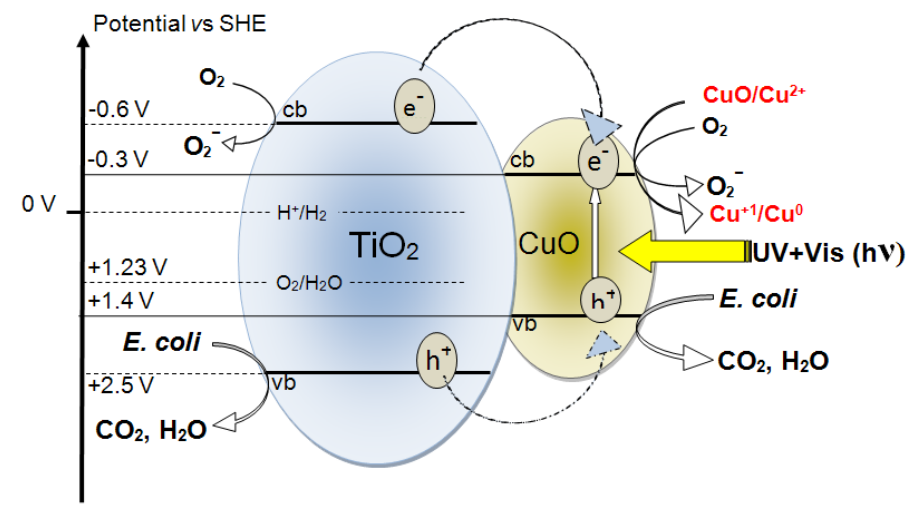

Figure 11. Scheme of bacteria inactivation under light on $\mathrm{Cu}-\mathrm{TiO}_{2}$ films on polyester.

The electronic transfer between the $\mathrm{TiO}_{2} / \mathrm{Cu}$ and E. coli depends on the length of the charge diffusion in the $\mathrm{TiO}_{2} / \mathrm{Cu}$. The diffusion is a function of the $\mathrm{TiO}_{2}$ and $\mathrm{Cu}$ particle size and shape $[101,121]$. The interfacial distances between $\mathrm{TiO}_{2}$ and $\mathrm{Cu} / \mathrm{CuO}$ on the polyester surface ranges from $5 \mathrm{~nm}$ and up. The IFCT, as shown in Figure 5, proceeds with high quantum efficiency depending on the applied light intensity and the nanoparticulate size and surface properties [155-158]. Quantum size effects occur in particles with sizes $\sim 10 \mathrm{~nm}$ that have about $10^{4}$ atoms (Figure 9) [122]. The surface composition and properties of the $\mathrm{TiO}_{2}-\mathrm{CuO}$ play a role in the charge transfer kinetics involving: (a) surface defects; (b) surface imperfections; and (c) dangling bonds on the edge of this composite. Using XPS and atomic force microscopy (AFM), information on the surface composition and roughness has been partially reported [169]. In $\mathrm{TiO}_{2}-\mathrm{Cu}$ the charge recombination is short due to their small particle size. The small particle size decreases the space for charge separation. Also, the semiconductor space charge layer in both the $\mathrm{TiO}_{2}$ and $\mathrm{CuO}$ further decreases the potential depth available for the charge injection at the $\mathrm{TiO}_{2}-\mathrm{Cu}$ heterojunction. This decreases the energy difference between $\mathrm{TiO}_{2}$ and $\mathrm{Cu}$, which is not favorable for the charge injection $[43,56,107]$. The conduction band of $\mathrm{CuO}$ at $-0.30 \mathrm{~V}$ vs. SCE (pH 7) in Figure 5 is at a more negative potential than the potential required for one electron oxygen reduction $[125,155-158]$. Furthermore, the $\mathrm{Cu}^{2+}$ can also react with $\mathrm{O}_{2}{ }^{-}$

$$
\begin{gathered}
\mathrm{O}_{2}+\mathrm{H}^{+}+\mathrm{e}^{-} \rightarrow \mathrm{HO}_{2}^{\bullet}-0.22 \mathrm{~V} \\
\mathrm{Cu}^{2+}+\mathrm{O}_{2}^{-} \rightarrow \mathrm{Cu}^{+}+\mathrm{O}_{2}
\end{gathered}
$$


A recent study addressed the inactivation of E. coli and MRSA on co-sputtered $\mathrm{TiO}_{2}-\mathrm{Cu}$ to compare the PES sputtered samples in the dark and under light on Gram-negative and Gram-positive bacteria [170]. The $\mathrm{TiO}_{2}$-Cu-PES was obtained by direct current magnetron co-sputtering for $3 \mathrm{~min}$ and induced Gram-negative E. coli inactivation within $120 \mathrm{~min}$ in the dark within 30 min under low intensity actinic light. The inactivation of MRSA (with an intial concentration of $10^{6} \mathrm{CFU} / \mathrm{mL}$ ) on co-sputtered $\mathrm{TiO}_{2}-\mathrm{Cu}$ attained $99.99 \%$ within $120 \mathrm{~min}$ in the dark and within 30 min under indoor actinic light irradiation, as shown in Figure 6a. Cu was released in ppb amounts during the bacterial inactivation as detected by inductively coupled plasma-mass spectrometry (ICP-MS), suggesting an oligodynamic effect.

Figure 12 trace 1 shows bacterial inactivation within $30 \mathrm{~min}$ for $\mathrm{TiO}_{2}-\mathrm{Cu}$ co-sputtered for $3 \mathrm{~min}$. This film was determined by profilometry to be $135 \mathrm{~nm}$ thick (about 700 atomic layers) consisting of $0.16 \% \mathrm{Cu}$ weight $/ \mathrm{TiO}_{2} 0.14 \%$ by weight on PES as determined by X-ray fluorescence (XRF) on the PES substrate [169]. This coating provides a sufficient amount of $\mathrm{TiO}_{2}$ and $\mathrm{Cu}$ on the PES to interact meaningfully with bacteria. Co-sputtering for 1 and $2 \mathrm{~min}$ did not induce the necessary amount of $\mathrm{TiO}_{2}$ and $\mathrm{Cu}$-sites, leading to an accelerated bacterial inactivation.

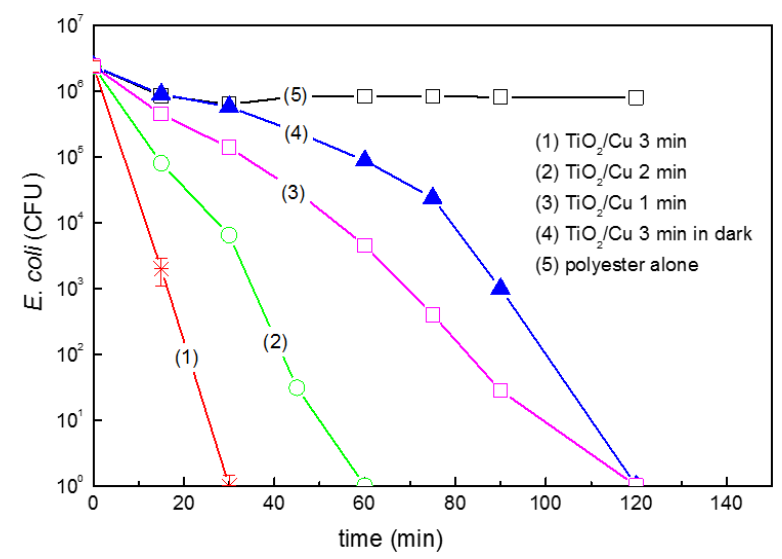

Figure 12. E. coli inactivation on $\mathrm{TiO}_{2}-\mathrm{Cu}$ co-sputtered for different times on polyester (PES) as indicated in the traces: (1) $3 \mathrm{~min}$, (2) $2 \mathrm{~min}$, (3) $1 \mathrm{~min}$, (4) co-sputtered $\mathrm{TiO}_{2}-\mathrm{Cu}$ for $3 \mathrm{~min}$ in the dark and (5) PES-alone. The bacterial reduction under light irradiation used a Philips Master-18W/865 lamp $\left(4.65 \mathrm{~mW} / \mathrm{cm}^{2}\right)$.

Next, we address the issue of the MRSA bacterial inactivation kinetics and relate the inactivation time to the applied light intensity. A longer inactivation time was observed for MRSA compared to E. coli under light irradiation. This is shown in Figures 12 and 13. The difference in wall thickness, number of layers, peptidoglycan content, lipid and protein content, and lipopolysaccharide (LPS) content seems to account for the different bacterial inactivation kinetics observed for E. coli and MRSA $[6-9,13,64,136]$. The electrostatic interaction of the Cu NPs-positive-ions interacting with the negative lipopolysaccharide (LPS) of E. coli will certainly be different to the interaction of the Cu-NPs ions interacting with the positive outer layer of MRSA. Figure 13a shows the MRSA inactivation time in the dark under different conditions and for different MRSA loadings. Next, Figure 13b shows MRSA inactivation under three different light intensities. The MRSA inactivation in the dark and under actinic light irradiation occurred within similar times, suggesting an inactivation mechanism completely different to the one leading to the inactivation of E. coli (Figure 12). Some studies have recently appeared in the literature about the inactivation of Gram-negative and Gram-positive bacteria on Cu-composites [171,172]. 

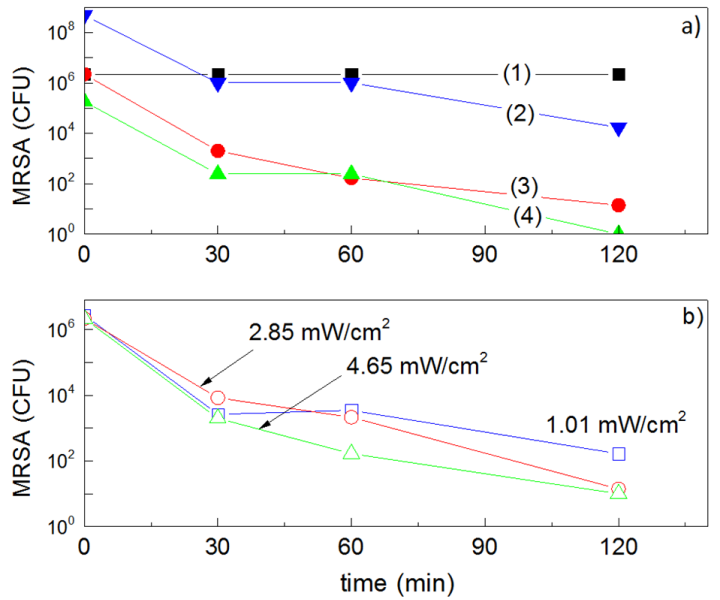

Figure 13. (a) Effect of the initial bacterial concentration of MRSA loss of viability on: (1) Unsputtered PES and by co-sputtered $\mathrm{TiO}_{2} / \mathrm{Cu}$-PES for $3 \mathrm{~min}$ tested in the dark: (2) $10^{8} \mathrm{CFU} / \mathrm{mL}$, (3) $10^{6} \mathrm{CFU} / \mathrm{mL}$ and (4) $10^{5} \mathrm{CFU} / \mathrm{mL}$. (b) Effect of light intensity on MRSA loss of viability on co-sputtered $\mathrm{TiO}_{2} / \mathrm{Cu}-\mathrm{PES}$ for 3 min under: $1.01,2.85$, and $4.65 \mathrm{~mW} / \mathrm{cm}^{2}$.

During the last two years, some studies reported the sputtering of binary oxide Cu promoted films. Reports on their bacterial inactivation kinetics, adhesion, and mechanical strength seem encouraging at this stage. The long-term operational lifetime and inactivation mechanism have been reported alongside the amount of $\mathrm{Cu}$ released by these innovative surfaces during bacterial inactivation. These studies have shown a drastic enhancement of the bacterial inactivation kinetics of E. coli when $\mathrm{Cu}$ was added to binary-oxides in percentages from $0.01 \%$ (decoration) up to $1 \%$ (doping) $[119,127,173]$. A variety of $\mathrm{TiO}_{2}-\mathrm{Cu}$ preparations and the evaluation of their activity for diverse applications is an area of current interest [129-131,174].

The relevance of $\mathrm{TiO}_{2}-\mathrm{Cu}$ catalysts and photocatalysts addressing the issue of bacterial inactivation is reflected in the increasing number of studies focusing on the antibacterial effects of $\mathrm{TiO}_{2}-\mathrm{Cu}$ and $\mathrm{TiO}_{2} / \mathrm{Cu}$ in the form of $2 \mathrm{D}$-coatings, suspensions, spheres, alloys, and decorated binary oxides [175-181].

In Section 2.1, Equations (5)-(9) presented a scheme of reactions leading to bacterial inactivation by $\mathrm{TiO}_{2}$ sputtered on PE. A recent study presents evidence for binary $\mathrm{TiO}_{2}-\mathrm{ZrO}_{2}$ sputtered on PES behaving in a similar way to $\mathrm{TiO}_{2}$, but leading to shorter times of bacterial inactivation under band-gap irradiation [172]. Only ppb amounts decorating the surface of $\mathrm{TiO}_{2}-\mathrm{ZrO}_{2}$ and $\mathrm{TiO}_{2}$ were shown to be necessary to drastically accelerate bacterial reduction. The minimal amounts of $\mathrm{Cu}$ as determined by XRF were in the range of $0.01 \%-0.02 \%$ by weight (ppb range). The drastic effect of extremely low amounts of $\mathrm{Cu}$ released during the bacterial inactivation can be rationalized by the high toxicity of $\mathrm{Cu}\left(\mathrm{Cu}(\mathrm{I}) / \mathrm{Cu}(\mathrm{II})\right.$ species/oxides on the bacteria and cannot be ascribed to any doping of the $\mathrm{TiO}_{2}$ by $\mathrm{Cu}$, which requires much higher $\mathrm{Cu}$-amounts. Recent developments on flexible antibacterial sputtered coatings have been reported using $\mathrm{Cu}$ as a bactericide agent in the composite films [182-184].

\section{Conclusions}

The $\mathrm{Cu}$ and $\mathrm{TiO}_{2}$ semiconductors interact with the bacterial wall and the cytoplasm in the dark and under light conditions by mechanisms that remain controversial. This review focused on uniform, stable, and reproducible $\mathrm{Cu} / \mathrm{TiO}_{2}$ or $\mathrm{Cu}-\mathrm{TiO}_{2}$ films obtained by sequential sputtering or by co-sputtering. Accelerated bacterial inactivation kinetics were observed by the co-sputtered films compared to the sequentially sputtered films in the dark or under indoor visible light irradiation. The evaluation of the bacterial inactivation kinetics, the disinfection stability, and last but not least, the properties of the sputtered films leading to the bacterial inactivation were addressed in detail. 
Considerable savings in metal and deposition time (energy) was found by using HIPIMS sputtering compared to conventional DCMS/DCMSP sputtering. This is important due to the increasing demand for $\mathrm{Cu}$, which is rapidly decreasing the known $\mathrm{Cu}$ reserves in the world. It seems that the biocide properties of $\mathrm{Cu}$ drastically increase the bactericidal properties of $\mathrm{TiO}_{2}$. Progress in the knowledge of the molecular mechanism implicated in the bacteria- $\mathrm{TiO}_{2} / \mathrm{Cu}$ is needed to design and synthesize more effective antibacterial biomaterial-composites. This is an important point in view of the current limitations of the use of antibiotics over long time periods and the increasing resistance of many toxic pathogens to antibiotic/antiseptic formulations. The photocatalysis mediated by $\mathrm{TiO}_{2}, \mathrm{Cu}$, and $\mathrm{Cu} / \mathrm{TiO}_{2}$ under light and for Cu-containing surfaces in the dark led to bacterial inactivation for E. coli and MRSA. The oxidative intermediate radicals generated during the photocatalysis degrade/mineralize both types of bacteria independently of the specific bacterial charge.

Acknowledgments: The authors thank the support by the EPFL and the financial support by the Swiss National Science Foundation under Grant No 2000021-143283/1.

Author Contributions: S.R. carried out the sputtering of the $\mathrm{Cu} / \mathrm{TiO}_{2}$ and $\mathrm{TiO}_{2}-\mathrm{Cu}$ films, their characterization, and biological evaluation. C.P. contributed with his microbiological and catalytic/photocatalytic experience to the studies presented in this review. J.K. participated in the overall work leading to this review and coordinated the layout of the final write-up with S.R. The authors gave their final approval for the submitted manuscript and are accountable for the material presented in this review.

Conflicts of Interest: The authors declare no conflict of interest.

\section{References}

1. Mikolay, A.; Hugget, S.; Tikana, L.; Grass, G.; Braun, J.; Nies, D. Survival of bacteria on metallic copper surfaces in a hospital trial. Appl. Microbiol. Biotechnol. 2010, 87, 1875-1879. [CrossRef] [PubMed]

2. Sunada, K.; Watanabe, T.; Hashimoto, K. Bactericidal activity of copper-deposited $\mathrm{TiO}_{2}$ films under weak UV-light illumination. Environ. Sci. Technol. 2003, 37, 4785-4789. [CrossRef] [PubMed]

3. Nozik, A. Photo-electrochemistry: Applications to Solar Energy Conversion. Annu. Rev. Phys. Chem. 1978, 189, 521-549.

4. Yadava, H.; Otaria, S.; Kolia, V.; Malib, S.; Hong, C.; Pawara, S.; Delekara, S. Preparation and characterization of copper-doped anatase $\mathrm{TiO}_{2}$ nanoparticles with visible light photocatalytic antibacterial activity. J. Photochem. Photobiol. A Chem. 2014, 280, 32-38. [CrossRef]

5. Rtimi, S.; Giannakis, S.; Bensimon, M.; Pulgarin, C.; Sanjines, R.; Kiwi, J. Supported $\mathrm{TiO}_{2}$ films deposited at different energies: Implications of the surface compactness on the catalytic kinetics. Appl. Catal. B 2016, 191, 42-52. [CrossRef]

6. Robin, S.; Soulimane, T.; Lavelle, S. Interactions of Biofilm-forming Bacteria with Abiotic Surfaces. In Biological Interactions with Surface Charges in Biomaterials; Tofail, S.A.M., Ed.; RSC: London, UK, 2012.

7. Lejeune, P. Contamination of abiotic surfaces: What a colonizing bacterium sees and how blur it. Trends Microbiol. 2003, 11, 179-184. [CrossRef]

8. Bernstein, R.; Freger, V.; Lee, J.; Kim, Y.; Lee, J.; Herzberg, M. Should I stay or should I go? Bacterial attachment vs. biofilm formation on surface-modified membranes. Biofouling 2014, 30, 367-376. [CrossRef] [PubMed]

9. Francolini, I.; Norris, P.; Piozzi, A.; Donello, G.; Stoodley, P. Usnic acid, a natural antimicrobial agent able to inhibit bacterial biofilm formation on polymer surfaces. Antimicrob. Agents Chemother. 2001, 48, 4360-4365. [CrossRef] [PubMed]

10. Francolini, I.; Donelli, G. Prevention and control of biofilm-based medical device-related infections. FEMS Immunol. Med. Microbiol. 2010, 59, 227-238. [CrossRef] [PubMed]

11. Hoiby, N.; Bjarnsholt, T.; Givskov, M.; Molin, S.; Ciofu, O. Antibiotic resistance of bacterial biofilms. Int. J. Antimicrob. Agents 2010, 35, 322-332. [CrossRef] [PubMed]

12. Byrne, A.-J.; Dunlop, M.S.P.; Hamilton, J.W.J.; Fernandez-Ibanes, P.; Polo-Lopez, I.; Sharma, K.P.; Vennard, M.S.A. A review of heterogeneous photocatalysis for water and surface disinfection. Molecules 2015, 20, 5574-5615. [CrossRef] [PubMed]

13. Canpoccia, D.; Montanaro, L.; Arciola, C. A review of the biomaterials technologies for infection resistant surfaces. Biomaterials 2013, 34, 8533-8554. [CrossRef] [PubMed] 
14. Sun, D.; Shahzad, B.; Li, M.; Wang, G.; Xu, D. Antimicrobial materials with medical applications. Mater. Technol. Adv. Biomater. 2015, 30, B30-B95. [CrossRef]

15. Klevens, R.M.; Edwards, J.R.; Richards, C.L., Jr.; Horan, T.C.; Gaynes, R.P.; Pollock, D.A.; Cardo, D.M. Estimating health care-associated infections and deaths in U.S. hospitals, 2002. Public Health Rep. 2007, 122, 160-166. [CrossRef] [PubMed]

16. Zarb, P.; Coignard, B.; Griskeviciene, J.; Muller, A.; Vankerckhoven, V.; Weist, K.; Goossens, M.; Vaerenberg, S.; Hopkins, S.; Catry, B.; et al. The European Centre for Disease Prevention and Control (ECDC) pilot point prevalence survey of healthcare-associated infections and antimicrobial use. Euro Surveill. 2012, 17, 20316. [PubMed]

17. Boucher, H.W.; Talbot, G.H.; Bradley, J.S.; Edwards, J.E.; Gilbert, D.; Rice, L.B.; Scheld, M.; Spellberg, B.; Bartlett, J. Bad bugs, no drugs: No ESKAPE! An update from the Clinical infectious diseases Infectious. Dis. Soc. Am. 2009, 48, 1-12.

18. Bhalla, A.M.D.; Pultz, N.J.B.S.; Gries, D.M.M.D.; Ray, A.J.M.D.; Eckstein, E.C.R.N.; David, C.; Aron, M.D.; Donskey, C.J.M.D. Acquisition of Nosocomial Pathogens on Hands after Contact With Environmental Surfaces Near Hospitalized Patients. Infect. Control Hosp. Epidemiol. 2004, 25, 164-167. [CrossRef] [PubMed]

19. French, G.L.; Otter, J.A.; Shannon, K.P.; Adams, N.M.; Watling, D.; Parks, M.J. Tackling contamination of the hospital environment by methicillin-resistant Staphylococcus aureus (MRSA): A comparison between conventional terminal cleaning and hydrogen peroxide vapour decontamination. J. Hosp. Infect. 2004, 57, 31-37. [CrossRef] [PubMed]

20. Abreu, A.C.; Tavares, R.R.; Borges, A.; Mergulhao, F.; Simoes, M. Current and emergent strategies for disinfection of hospital environments. J. Antimicrob. Chemother. 2013, 68, 2718-2732. [CrossRef] [PubMed]

21. Matsunaga, T.; Tomoda, R.; Nakajima, T.; Nakamura, N.; Komine, T. Continuous-Sterilization System that Uses Photosemiconductor Powders. Appl. Environ. Microbiol. 1988, 54, 1330-1333. [PubMed]

22. Fujishima, A.; Hashimoto, K.; Watanabe, W. TiO 2 Photocatalysis Fundamentals and Applications; Bkc Inc.: Tokyo, Japan, 1999.

23. Taylor, K.; Roberts, J.; Roberts, J. The Challenge of Hospital Acquired Infections (HAI); National Audit Office: London, UK, 2002.

24. Talon, D. The role of the hospital environment in the epidemiology of multi-resistant bacteria. J. Hosp. Infect. 1999, 43, 13-17. [CrossRef] [PubMed]

25. Kramer, A.; Schwebke, I.; Kampf, G. How long do nosocomial pathogens persist on inanimate surfaces? A systematic review. BMC Infect. Dis. 2006, 6, 130-139. [CrossRef] [PubMed]

26. Dancer, S.J. The role of environmental cleaning in the control of hospital-acquired infection. J. Hosp. Infect. 2009, 73, 378-385. [CrossRef] [PubMed]

27. Pakrashi, S.; Kumar, R.; Chandrasekaran, N.; Mujerkee, A. A comparative cytotoxicity study of $\mathrm{TiO}_{2}$ nanoparticles under light and dark conditions at low light exposure concentrations. Toxicol. Res. 2012, 1, 116-130.

28. Zhang, L.; Luo, Z.; Song, L.; Shi, X.; Pan, Y.; Fan, Y.; Xu, Y. Effects and mechanisms of waterborne copper exposure influencing ovary development and related hormones secretion in yellow catfish Pelteobagrus fulvidraco. Aquat. Toxicol. 2016, 178, 88-98. [CrossRef] [PubMed]

29. Anderl, J.; Franklin, M.; Stewart, R. Role of antibiotic penetration limitation in Klebsiella pneumoniae biofilm resistance to ampicillin and ciprofloxacin. J. Antomicrob. Agents Chemother. 2000, 44, 1818-1824. [CrossRef]

30. Matsunaga, T.; Tomoda, R.; Nakajima, T.; Wake, H. Photoelectrochemcal sterilization of microbial cells by semiconductor powders. FEMS Microb. Lett. 1985, 29, 211-214. [CrossRef]

31. Foster, H.; Ditta, I.; Varghese, S.; Steele, A. Photocatlytic disinfection using titanium dioxide: Spectrum and mechanism of antimicrobial activity. Appl. Microbiol. Biotechnol. 2011, 90, 1847-1868. [CrossRef] [PubMed]

32. Pigeot-Rémy, S.; Simonet, F.; Errazuriz-Cerda, E.; Lazzaroni, J.; Atlan, D.; Gillard, C. Photocatalysis and disinfection of water: Identification of potential bacterial targets. Appl. Catal. B 2011, 104, 390-398. [CrossRef]

33. Markowska-Szczupak, A.; Ulgig, K.; Morawski, A. The applicationot titanium dioxide for deactivation of bioparticulates: An overview. Catal. Today 2011, 169, 249-257. [CrossRef]

34. Robertson, P.; Robertson, J.; Bahnemann, D. Removal of microorganisms and their chemical metabolites from water using semiconductors photocaatlysis. J. Hazard. Mater. 2012, 211-212, 162-171.

35. Dalrymple, O.; Isaaks, W.; Stefanakos, E.; Trotz, M.; Goswami, D. Lipid vesicles a smodel membranes in photocatalytic disinfection studies. J. Photochem. Photobiol. A 2011, 221, 64-70. [CrossRef] 
36. Gamage, J.; Zhang, Z. Applications of Photocatalytic Disinfection: A review. Int. J. Photo-Energy 2010, 2010, 764870. [CrossRef]

37. Kubacka, A.; Diez, M.S.; Rojo, D.; Bargiela, R.; Ciordia, S.; Zapico, I.; Albar, J.P.; Barbas, C.; Martins dos Santos, V.A.P.; Fernández-García, M.; et al. Understanding the antimicrobial mechanism of $\mathrm{TiO}_{2}$-based nanocomposite films in a pathogenic bacterium. Sci. Rep. 2014, 4, 4134-4143. [CrossRef] [PubMed]

38. Dalrymple, O.; Stefanakos, E.; Trotz, M.; Goswami, Y. A review of the mechanism and modeling of photocatalytic disinfection. Appl. Catal. B 2010, 98, 27-38. [CrossRef]

39. Farr, S.; Kogoma, T. Oxidative stress responses in Escherrichia coli and Salmonella triphimurium. Microbiol. Rev. 1991, 55, 561-585. [PubMed]

40. Kiwi, J.; Nadtochenko, V. New evidence for $\mathrm{TiO}_{2}$ photocatalysis during bilayer lipid-peroxidation. J. Phys. Chem. B 2004, 108, 17675-17684. [CrossRef]

41. Linsebliger, A.; Lu, G.; Yates, J. Photocatalysis on $\mathrm{TiO}_{2}$ Surfaces. Principles, Mechanisms and Selected Results. Chem. Rev. 1996, 95, 735-758. [CrossRef]

42. Nakano, R.; Hara, M.; Ishiguro, H.; Yao, Y.; Ochiai, T.; Nakata, K.; Murakami, T.; Kajioka, J.; Sunada, K.; Hashimoto, K.; et al. Broad Spectrum Microbicidal Activity of Photocatalyis by $\mathrm{TiO}_{2}$. Catalysts 2013, 3, 310-323. [CrossRef]

43. Fujishima, A.; Zhang, X.; Tryk, D. $\mathrm{TiO}_{2}$ photocatalysis and related surface phenomena. Surf. Sci. Rep. 2008, 63, 515-582. [CrossRef]

44. Daoud, W. Self-Cleaning Materials and Surfaces, a Nanotechnology Approach; Wiley: Chichester, UK, 2013.

45. Griesser, H.J. Chapter 16: Uniform, adhesive and low cytotoxic films accelerating bacterial reduction in the dark and under visible light. In The Film Coatings for Biomaterials and Biomedical Applications; Rtimi, S., Pulgarin, C., Kiwi, J., Eds.; Elsevier Ltd.: London, UK, 2016.

46. Kiwi, J.; Rtimi, S. Chapter 3: Environmentally mild self-cleaning processes on textile surfaces under daylight irradiation: Critical Issues. In Active Coatings for Smart Textiles; Hu, J., Ed.; Elsevier Ltd.: Cambridge, UK, 2016.

47. Rtimi, S.; Sanjines, R.; Kiwi, J.; Pulgarin, C.; Bensimon, M.; Khmel, I.; Nadtochenko, V. Innovative photocatalysts $\left(\mathrm{FeO}_{\mathrm{x}}-\mathrm{TiO}_{2}\right)$ : Transients by femtosecond laser pulse leading to bacterial inactivation under visible light. RSC Adv. 2015, 5, 101751-101759. [CrossRef]

48. Rtimi, S.; Pulgarin, C.; Nadtochenko, V.; Gostev, F.; Shelaev, I.; Kiwi, J. FeO $\mathrm{F}_{\mathrm{x}}-\mathrm{TiO}_{2}$ Film with Different Microstructiures Leading to Femtosecond Transients with Different Properties: Biological Implications under Visible Light. Nat. Sci. Rep. 2016, 6, 30113. [CrossRef] [PubMed]

49. Pelaez, M.; Nolan, T.; Pillai, C.S.; Seery, K.; Falaras, P.; Kontos, A.; Dunlop, M.; Dunlop, H.J.; Byrne, A.-J.; O'Shea, K.; et al. A review on the visible light active titanium dioxide photocatalysts for environmental applications. Appl. Catal. B 2012, 125, 331-349. [CrossRef]

50. Banerjee, S.; Pillai, C.S.; Falaras, P.; O'Shea, K.; Byrne, A.-J.; Dionysiou, D. New Insights into the Mechanism of Visible Light Photocatalysis. J. Phys. Chem. Lett. 2014, 5, 2543-2554. [CrossRef] [PubMed]

51. Etacheri, V.; Di Valentin, C.; Schneider, D.; Bahnemann, D.; Pillai, C.S. Visible-light activation of $\mathrm{TiO}_{2}$ photocatalysts: Advances in theory and experiments. J. Photochem. Photobiol. C Rev. 2015, 25, 1-29. [CrossRef]

52. Banerjee, S.; Dionysiou, D.; Pillai, C.S. Self-cleaning applications of $\mathrm{TiO}_{2}$ by photo-induced hydrophilicity and photocatalysis. Appl. Catal. B 2015, 176-177, 396-428. [CrossRef]

53. Fagan, R.; Cormack, M.; Dionysiou, D.; Pillai, S. A review on solar and visible light active $\mathrm{TiO}_{2}$ photocatalysts for treating bacteria, cynotoxins and contaminants of emerging concern. Mater. Sci. Semicond. Process. 2016, 42, 2-14. [CrossRef]

54. Devi, G.; Kavitha, R. A review on non-metal ion doped-titania for photocatalytic degradation of organic pollutants under UV/solar light: Role of photogenerated charges dynamic in enhancing the activity. Appl. Catal. B 2013, 140-168, 559-587. [CrossRef]

55. Fotiou, T.; Triantis, T.; Kaloudis, T.; O'Shea, K.; Dionysiou, D.; Hiskia, A. Assessment of the roles of reactive oxygen species in the UV and visible light photocatalytic degradation of cyanotoxins and water taste and odor compounds using $\mathrm{C}-\mathrm{TiO}_{2}$. Water Res. 2016, 90, 52-61. [CrossRef] [PubMed]

56. Schneider, J.; Matsuoka, M.; Takeuchi, J.; Zhang, L.; Horiuchi, Y.; Anpo, M.; Bahnemann, D. Understanding $\mathrm{TiO}_{2}$ Photocatalysis: Mechanisms and Materials. Chem. Rev. 2014, 114, 9919-9986. [CrossRef] [PubMed] 
57. Wang, R.; Hashimoto, K.; Fujishima, K.; Chikuni, M.; Kojima, E.; Kitamura, A.; Shimohigoshi, M.; Watanabe, T. Light-induced amphiphilic surfaces. Nature 1997, 388, 431-432. [CrossRef]

58. Sakai, N.; Fujishima, A.; Watanabe, T.; Hashimoto, K. Enhancement of Photoinduced Hydrophilic Conversion Rate of $\mathrm{TiO}_{2}$ Film Electrode Surface of Anodic Polarization. J. Phys. Chem. B 2001, 105, 3023-3026. [CrossRef]

59. Miyauchi, M.; Nakajima, A.; Watanabe, T.; Hashimoto, K. Photocatalysis and Photoinduced Hydrophilicity of Various Metal Oxide Films. Chem. Mater. 2002, 14, 2812-2816. [CrossRef]

60. Rtimi, S.; Pulgarin, C.; Sanjines, R.; Kiwi, J. Innovative semi-transparent nanocomposite films presenting photo-switchable behavior and leading to a reduction of the risk of infection under sunlight. RSC Adv. 2013, 3, 16345-16349. [CrossRef]

61. Rtimi, S.; Sanjines, R.; Pulgarin, C.; Kulik, A.; Kiwi, J. Innovative transparent non-scattering $\mathrm{TiO}_{2}$ bactericide films inducing increased E. coli cell fluidity. Surf. Coat. Technol. 2014, 254, 333-343. [CrossRef]

62. Pulgarin, C.; Kiwi, J.; Nadtochenko, V. Mechanism of the photocatalytic destruction of bacteria by $\mathrm{TiO}_{2}$ films leading to cell-wall damages and bacterial lysis. Appl. Catal. B 2012, 128, 179-183. [CrossRef]

63. Jayachandran, Y.; Narayandass, S. The effect of thickness of Ti-nitride coatings on bacterial adhesion. Trends Biomater. Artif. Organs 2010, 24, 90-93.

64. Rio, L.; Kusiak, E.; Kiwi, J.; Pulgarin, C.; Trampuz, C.; Bizzini, A. Comparative methods to evaluate the bactericidal activity of copper-sputtered surfaces against methicillin-resistant Staphylococcus aureus. Appl. Environ. Microbiol. 2012, 78, 8176-8182. [CrossRef] [PubMed]

65. Poole, R.; Kumar, I.; SalmonI, I.; Chance, B. The 650 and chromophore in Escherichia coli is oxy oxygenated compound, not the oxidized form of cytochrome oxidase: An hypothesis. J. Gen. Microbiol. 1983, 129, 1335-1344. [CrossRef] [PubMed]

66. Van Loosdrecht, L.; Lyklema, M.; Norde, W.; Schraa, G.; Zender, A. The role of bacterial cell-wall hydrophobicity in adhesion. Appl. Environ. Microbiol. 1987, 53, 1893-1990. [PubMed]

67. Xu, L.; Wellia, D.; Amal, R.; Liao, W.; Loo, J.; Tan, T. Fabrication of Highly Ordered $\mathrm{TiO}_{2} \mathrm{Nanorod}_{\text {Nanotube }}$ Adjacent Array for Photo-electrochemical Applications. Langmuir 2010, 2, 1122-1128.

68. Hogt, A.; Dankert, J.; Feijen, J. Adhesion of Staphyloccocus epidermis and Staphyloccocus Saprophyticus to a hydrophobic biomaterial. J. Gen. Microbiol. 1985, 131, 2485-2491. [PubMed]

69. Fletcher, R.; Loeb, M. Influence of the substratum characteristics on the attachment of a marine pseudomonas to solid surfaces. Appl. Environ. Microbiol. 1979, 37, 67-72. [PubMed]

70. Loveland, P.; Ryan, J.; Amy, G.; Harvey, R. The reversibility of virus attachment to mineral surfaces. Colloid Surf. A Physicochem. Eng. Aspects 1996, 107, 205-221. [CrossRef]

71. Zhukova, L.; Kiwi, J.; Nikandrov, V. Effect of the nanoparticles on Escherichia coli cell division capacity at $\mathrm{pH}$ 4-4.5 in the absence of UV-irradiation. J. Colloids Surf. Bio-Interfaces 2012, 97, 240-247. [CrossRef] [PubMed]

72. Nesic, J.; Rtimi, R.; Hebert, C.; Pulgarin, C.; Roglic, G.; Kiwi, J. New evidence for $\mathrm{TiO}_{2}$ uniform surfaces leading to complete bacterial reduction in the dark: Critical issues. Colloids Surf. B Biointerfaces 2014, 123, 593-599. [CrossRef] [PubMed]

73. Kaegi, R.; Ulrich, B.; Sinnet, R.; Vonbank, R.; Wichser, A.; Zuleeg, S.; Simler, S.; Brunner, H.; Vonmont, H.; Burkhart, M.; et al. Synthetic $\mathrm{TiO}_{2}$ nanoparticle emission from exterior facades into the aquatic environment. Environ. Pollut. 2008, 156, 233-239. [CrossRef] [PubMed]

74. Gottschalk, F.; Sonderer, T.; Scholz, W.; Nowack, B. Modeled Environmental Concentrations of Engineered Nanomaterials (ENM) for different regions and at different resolutions. Environ. Sci. Technol. 2009, 43, 9216-9222. [CrossRef] [PubMed]

75. Tong, T.; Shereef, A.; Wu, J.; Binh, C.; Kelly, J.; Gaillard, J.; Gray, K. Effects of the material morphology on the phototoxicity of nano-TiO 2 to bacteria. Environ. Sci. Technol. 2013, 49, 8113-8123. [CrossRef] [PubMed]

76. Lewinski, N.; Colvin, V.; Drezek, R. Cytotoxicity of Nanoparticles. Small 2008, 4, 26-49. [CrossRef] [PubMed]

77. Rincon, A.G.; Pulgarin, C. Photocatlytical inactivation of E. coli: Effect of the continuous-intermittent light intensity and of suspended fixed $\mathrm{TiO}_{2}$ concentration. Appl. Catal. B 2003, 44, 263-284. [CrossRef]

78. Rincon, A.G.; Pulgarin, C. Bactericidal action of illuminated $\mathrm{TiO}_{2}$ on pure Escherichia coli and natural bacterial consortia: Post-irradiation events in the dark and assessment of the effective disinfection time. Appl. Catal. B 2004, 112, 99-112. [CrossRef]

79. Miyauchi, M.; Irie, H.; Liu, M.; Qiu, X.; Yu, H.; Sunada, K.; Hashimoto, K. Visible-Light-Sensitive Photocatalysis: Nanocluster-Grafted Titanium Dioxide for Indoor Environmental remediation. J. Phys. Chem. Lett. 2016, 7, 75-84. [CrossRef] [PubMed] 
80. Yoriya, S.; Chumphu, A.; Pookmanee, P.; Laithong, W.; Thepa, S.; Songprakorp, R. Multi-layered $\mathrm{TiO}_{2}$ films towards enhancement of Escherichia coli inactivation. Materials 2016, 9, 808. [CrossRef]

81. Rtimi, S.; Pulgarin, C.; Sanjines, R.; Kiwi, J. Kinetics and mechanism for transparent polyethylene-TiO films mediated self-cleaning leading to MB dye discoloration under sunlight irradiation. App. Cat. B Environ. 2015, 162, 236-244. [CrossRef]

82. Dunlop, P.S.M.; McMurray, T.A.; Hamilton, J.W.; Byrne, J.A. Inactivation of clinically relevant pathogens by photocatalytic coatings. Photochem. Photobiol. A 2010, 196, 113-119. [CrossRef]

83. McCullagh, C.; Robertson, C.; Bahnemann, D.; Robertson, K. The application of $\mathrm{TiO}_{2}$ photocatalysisfor disinfection of water contaminated with pathogenic micro-orgnisms: A review. Res. Chem. Intermed. 2007, 33, 359-375. [CrossRef]

84. Amenazaga-Madrid, P.; Silveyra-Morales, R.; Cordoba-Fierro, L.; Orianda-Borunda, E.; Soli, J. TEM evidence of ultrastructural alteration on Pseudomonas aeruginosa by photocatlytic $\mathrm{TiO}_{2}$ thin films. J. Photochem. Photobiol. B 2003, 70, 45-50. [CrossRef]

85. Mendez-Hermida, F.; Ares-Mazas, E.; McGuigan, G.; Boyle, M.; Sichel, C.; Fernandez-Ibanez, P. Disinfection of drinking water contaminated with Crystosporidium parvum oocysts under natural sunlight and using the photocatlyst $\mathrm{TiO}_{2}$. J. Photochem. Photobiol. B 2007, 66, 105-111. [CrossRef] [PubMed]

86. Watts, J.; Kong, S.; Orr, P.; Miller, C.; Henry, E. Photocatalytic inactivation of coliform bacteria and viruses in secondary waste water effluents. Water Res. 1995, 29, 95-100. [CrossRef]

87. Lincous, A.; Carter, J.; Locuson, B.; Oulette, J.; Slattery, K.; Smith, A. Photocatalytic inhibition of algae growth using $\mathrm{TiO}_{2}, \mathrm{WO}_{3}$ and cocatalysts modifications. Environ. Sci. Technol. 2000, 34, 4752-4758. [CrossRef]

88. Sichel, C.; de Cara, M.; Tello, J.; Blanco, J.; Fernandez-Ibanez, P. Solar photocatalytic disinfection of agricultural pathogenic fungi: Fusarium species. Appl. Catal. B 2007, 74, 152-160. [CrossRef]

89. Kuhn, P.; Chaberny, F.; Massholder, K.; Stickler, M.; Benz, W.; Sonntag Gerdinger, L. Disinfection of surfaces by photocatalytic oxidation with titanium oxide und UV-light. Chemosphere 2003, 53, 51-57. [CrossRef]

90. Zhang, L.; Dillert, R.; Bahnemann, D.; Vormoor, M. Photo-induced hydrophilicity and self-cleaning: Models and reality. Energy Environ. Sci. 2012, 5, 7491-7507. [CrossRef]

91. Nakano, T.; Baba, S. Gas pressure effects on thickness uniformity and circumvented deposition during sputter deposition. Vacuum 2006, 80, 647-840. [CrossRef]

92. Dunill, C.W.; Aiken, Z.A.; Pratten, M.; Wilson, M.; Parkin, P.I. Sulfur- and Nitrogen-Doped Titania Biomaterials via APCVD. Chem. Vap. Depos. 2010, 16, 50-54. [CrossRef]

93. Evans, P.; Sheel, D. Photoactive and Antibacterial Thin Films on Stainless Steel. Surf. Coat. Technol. 2007, 201, 9319-9324. [CrossRef]

94. Foster, H.A.; Sheel, D.W.; Shel, P.; Evans, P.; Varghese, S.; Rutschke, N.; Yates, M.H. Antimicrobial activity of titania/silver and titania/copper films prepared by CVD. J. Photochem. Photobiol. A 2010, 216, 283-289. [CrossRef]

95. Caputo, G.; Nobile, C.; Buonsanti, R.; Lipp, T.; Manna, L.; Cingolani, R.; Cozzoli, P.; Atanssiou, A. Determination of surface properties of various substrates using $\mathrm{TiO}_{2}$ nano-rod coatings with tunable characteristics. J. Mater. Sci. 2008, 43, 3474-3480. [CrossRef]

96. Irie, H.; Washizuka, S.; Hashimoto, K. Hydrophilicity on carbon-doped $\mathrm{TiO}_{2}$ thin films under visible light. Thin Solid Films 2006, 510, 21-25. [CrossRef]

97. Scanlon, D.; Dunnill, W.D.; Buckeridge, J.; Shevlin, S.; Logsdail, S.; Scott, S.; Woodley, M.; Richard, C.; Catlow, A.; Powell, M.; et al. Band alignment of rutile and anatase $\mathrm{TiO}_{2}$. Nat. Mater. 2013, 12, $798-801$. [CrossRef] [PubMed]

98. Carneiro, J.; Teixeira, V.; Portinha, A.; Magalhães, A.; Newton, R.; Coutinho, P. Iron-doped photocatalytic $\mathrm{TiO}_{2}$ sputtered coatings on plastics for self-cleaning applications. Mater. Sci. Eng. B 2007, 138, 144-150. [CrossRef]

99. Miron, C.; Roca, A.; Cozorici, P.; Sirghi, L. Photo-induced bactericidal activity activity of $\mathrm{TiO}_{2}$ tin films obtained by radiofrequency magnetron sputtering deposition. J. Optoelectr. Adv. Mater. 2004, 7, 915-919.

100. Plowman, R.; Graves, R.; Griffin, N.; Taylor, L. The rate of added cost of hospital acquired infections. J. Hosp. Infect. 2001, 47, 198-204. [CrossRef] [PubMed]

101. Rossnagel, S.; Hopwood, J. Magnetron sputter deposition with high levels of metal ionization. Appl. Phys. Lett. 1993, 63, 3285-3287. [CrossRef] 
102. Kelly, P.J.; Arnell, D.R. Magnetron sputtering: A review of recent developments and applications. Vacuum 2000, 56, 159-172. [CrossRef]

103. Sarakinos, K.; Alami, J.; Konstantinidis, S. High power pulsed magnetron sputtering: A review on scientific and engineering state of the art. Surf. Coat. Technol. 2010, 204, 1661-1684. [CrossRef]

104. Kousznetsov, V.; Macak, K.; Schneider, J.; Helmersson, U.; Petrov, I. A novel pulsed magnetron sputter technique utilizing very high target power densities. Surf. Coat. Technol. 1999, 122, 290-293. [CrossRef]

105. Castro, C.; Pulgarin, C.; Osorio, P.; Giraldo, S.; Kiwi, J. Structure-reactivity relations of the Cu-cotton sputtered layers during E. coli inactivation in the dark and under light. J. Photochem. Photobiol. A 2010, 216, 295-302. [CrossRef]

106. Osorio, P.; Sanjines Ruales, C.; Castro, C.; Pulgarin, C.; Rengifo, J.-A.; Lavanchy, J.-A.; Kiwi, J. Antimicrobial $\mathrm{Cu}$-functionalized surfaces prepared by bipolar asymmetric DC-pulsed magnetron sputtering (PMS). J. Photochem. Photobiol. A 2011, 220, 70-76. [CrossRef]

107. Rtimi, S.; Baghriche, O.; Pulgarin, C.; Lavanchy, J.-C.; Kiwi, J. Growth of $\mathrm{TiO}_{2} / \mathrm{Cu}$ films by HIPIMS for accelerated bacterial loss of viability. Surf. Coat. Technol. 2013, 232, 804-813. [CrossRef]

108. Li, C.; Tian, X.; Gong, C.; Xu, J. The improvement of high power impulse magnetron sputtering performance by an external unbalanced magnetic field. Vacuum 2016, 133, 98-104. [CrossRef]

109. Nikaido, H.J. Prevention of Drug Access to Bacterial Targets. Permeability Barriers and Active Flux. Biol. Chem. 1994, 269, 3905-3909.

110. Borkow, G.; Gabbay, J. Putting copper into action: Copper impregnated products with potential biocidal activities. J. FASEB 2008, 18, 1728-1730. [CrossRef] [PubMed]

111. Borkow, G.; Gabbay, J. Biocidal Textiles can help fight nosocomial infections. Med. Hypothesis 2008, 70, 990-994. [CrossRef] [PubMed]

112. Borkow, G.; Gabbay, J.; Dardik, R.; Eidelman, A.; Lavie, Y.; Grinfeld, Y.; Ikher, S.; Huszar, M.; Zatcoff, R.; Marikovsky, M. Molecular Mechanisms of enhanced wound healing by copper oxide-impregated dressing. Wound Rep. Reg. 2010, 18, 266-275. [CrossRef] [PubMed]

113. Borkow, G.; Gabbay, J. Copper an Ancient Remedy Returning to Fight Microbial, Fungal and Viral Infections. Curr. Chem. Biol. 2009, 3, 272-278. [CrossRef]

114. Applerot, G.; Abu-Mukh, R.; Irzh, R.; Charmet, J.; Keppner, J.; Laux, L.; Guilbert, G.; Gedanken, A. Decorative parylene coated glass with $\mathrm{ZnO}$ nano-particles for antibacterial applications. ACS Appl. Mater. Interfaces 2010, 2, 1052-1059. [CrossRef] [PubMed]

115. Perelshtein, I.; Applerot, N.; Perkas, N.; Wehrshuetz-Sigl, E.; Hasman, E.G.; Guebitz, G.; Gedanken, A. CuO-cotton nanocomposite: Formation, Morphology and bacterial activity. Surf. Coat. Technol. 2009, 204, 54-57. [CrossRef]

116. Torres, A.; Ruales, C.; Pulgarin, C.; Aimable, A.; Bowen, P.; Kiwi, J. Enhanced Inactivation of E. coli by RF-plasma Pre-treated Cotton/CuO $\left(65 \mathrm{~m}^{2} / \mathrm{g}\right)$ under Visible Light. Appl. Mater. Interfaces 2010, 1, 2547-2552. [CrossRef] [PubMed]

117. Kusiak-Nejman, E.; Morawski, A.; Ehiasarian, A.; Baghriche, O.; Pulgarin, C.; Mielczarski, E.; Mielczarski, J.; Kulik, A.; Kiwi, J. E. coli Inactivation by High Power Impulse Magnetron Sputtered (HIPIMS) Cu-Surfaces. J. Phys. Chem. C 2011, 115, 21113-21119. [CrossRef]

118. Haenle, M.; Fritsche, M.; Zietz, C.; Bader, M.; Heidenau, F. An extended spectrum bactericidal titanium dioxide $\left(\mathrm{TiO}_{2}\right)$ coating for metallic implants: In vitro effectiveness against MRSA and mechanical properties. J. Mater. Sci. Mater. Med. 2011, 22, 381-387. [CrossRef] [PubMed]

119. Rtimi, S.; Pulgarin, C.; Bensimon, M.; Kiwi, J. New Evidence for Cu-decorated binary-oxides mediating the bacterial inactivation/mineralization in aerobic media. Colloids Surf. B Biointerfaces 2016, 144, 222-228. [CrossRef] [PubMed]

120. Mathews, I. Epitaxial Growth, Part B; IBM Academic Press: New York, NY, USA, 1975; pp. $382-436$.

121. Ehasarian, P.A. High-power impulse magnetron sputtering and its applications. Pure Appl. Chem. 2010, 82, 1247-1258. [CrossRef]

122. Rtimi, S.; Pulgarin, C.; Baghriche, O.; Kiwi, J. Accelerated inactivation obtained by HIPIMS sputtering on low cost surfaces with concomitant reduction in the metal-semiconductor content. RSC Adv. 2013, 3, 13127-13130. [CrossRef]

123. Mishra, A.; Kelly, J.-P.; Bradley, W.-J. The 2D-plasma potential distribution in a HIPIMS discharge. J. Appl. Phys D Appl. Phys. 2011, 44, 425201. [CrossRef] 
124. Von Keudell, A.; Hecimovic, A.; Maszl, C. Control of High Power Pulsed Magnetron Discharge by Monitoring the Current Voltage Characteristics. Contrib. Plasma Phys. 2016, 56, 918-926. [CrossRef]

125. Petrov, I.; Myers, J.E.; Green, J.R.; Abelson, J. Mass and energy resolved detection of ions and neutral sputtered species incident at the substrate during reactive magnetron sputtering of Ti in mixed $\mathrm{Ar}+\mathrm{N}_{2}$ mixture. J. Vac. Sci. Technol. A 1994, 12, 2846-2851. [CrossRef]

126. Kousznetsov, V.; Mazak, K.; Schneider, J.; Helmersson, U.; Petrov, I. Ionized sputter-deposition using an extremely high plasma density pulsed magnetron discharge. Surf. Coat. Technol. 1999, 12, $20-295$.

127. Song, Y.; Kwon, Y.; Choi, G.; Lee, W. Photocatalyric activity of $\mathrm{Cu} / \mathrm{TiO}_{2}$ with oxidation state of surface loaded copper. Bull. Korean Chem. Soc. 1999, 20, 957-960.

128. Yu, J.; Ran, J. Facile preparation and enhanced photocatlytic activity $\mathrm{H}_{2}$-production activity of $\mathrm{Cu}(\mathrm{OH})_{2}$ cluster modified $\mathrm{TiO}_{2}$. Energy Environ. Sci. 2011, 4, 1364-1371. [CrossRef]

129. Lopez-Ayala, S.; Rincon, E.M. Catalytic and photocatalytic performance of mesoporous $\mathrm{Cu}_{\mathrm{x}} \mathrm{O}-\mathrm{TiO}_{2}$. J. Photochem. Photobiol. A 2011, 222, 249-257. [CrossRef]

130. Rodriguez-Torres, C.; Golmar, F.; Cabrera, A.; Errico, L.; Mudara-Navarro, M.A.; Renteria, M.; Sanchez, F.; Duhalde, S. Magnetic and structural study of Cu-doped $\mathrm{TiO}_{2}$ thin films. Appl. Surf. Sci. 2007, 254, 365-367. [CrossRef]

131. Audronis, M.; Hinder, S.; Mack, P.; Bellido-Gonzales, V.; Bussey, D.; Mathews, A.; Baker, M. A comparison of reactive plasma pretreatments on PET substrates by $\mathrm{Cu}$ and Ti pulsed-DC and HIPIMS discharges. Thin Solid Films 2011, 520, 1564-1570. [CrossRef]

132. Ballo, M.; Rtimi, S.; Mancini, S.; Kiwi, J. Bactericidal activity and mechanism of action of copper sputtered flexible surfaces against multidrug-resistant pathogens. Appl. Microbiol. Cell Physiol. 2016, 100, 5945-5953. [CrossRef] [PubMed]

133. Warnes, S.L.; Keevil, C.W. Mechanism of copper surface toxicity in vancomycin-resistant enterococci following wet or dry surface contact. Appl. Environ. Microbiol. 2011, 77, 6049-6059. [CrossRef] [PubMed]

134. Sands, K.; Vineyard, G.; Platt, R. Surgical site infections occurring after hospital discharge. J. Infect. Dis. 1996, 173, 963-970. [CrossRef] [PubMed]

135. Gharsa, H.; Dziri, R.; Klibi, N.; Chairat, S.; Lozano, C.; Torres, C.; Bellaaj, R.; Ben Slama, K. Environmental Staphylococcus aureus contamination in a Tunisian hospital. J. Chemother. 2016, 28, 506-509. [CrossRef] [PubMed]

136. Quaranta, D.; Krans, T.; Espirito Santo, C.; Elowsky, C.; Domaille, D.; Chang, C.; Grass, G. Mechanisms of contact-mediated killing of yeast cells on dry metallic copper surfaces. Appl. Environ. Microbiol. 2011, 77, 416-426. [CrossRef] [PubMed]

137. Espirito Santo, C.; Lam, E.; Elowsky, C.; Quaranta, D.; Domaille, D.; Chang, C.; Grass, G. Bacterial killing by dry metallic copper surfaces. Appl. Environ. Microbiol. 2011, 77, 794-802. [CrossRef] [PubMed]

138. Grass, G.; Rensing, C.; Solioz, M. Metallic copper as an antimicrobial surface. Appl. Environ. Microbiol. 2011, 77, 1541-1547. [CrossRef] [PubMed]

139. Casey, A.L.; Adams, D.; Karpanen, T.J.; Lambert, P.A.; Cookson, B.D.; Nightingale, P.; Miruszenko, L.; Shilla, R.; Christian, P.; Elliot, T.S. Role of copper in reducing hospital environment contamination. J. Hosp. Infect. 2010, 74, 72-77. [CrossRef] [PubMed]

140. Heidenau, F.; Mittelmeir, W.; Detsch, R.; Haenle, M.; Stenzel, F.; Ziegler, G. A novel antibacterial titania coating: Metal ion toxicity in vitro surface colonization. J. Mater. Sci. Med. 2005, 16, 883-888. [CrossRef] [PubMed]

141. Edgeworth, J. Intravascular catheter infections. J. Hosp. Infect. 2010, 73, 323-330. [CrossRef] [PubMed]

142. O'Grady, N.P.; Alexander, M.; Burns, L.A.; Dellinger, E.P.; Garland, J.; Heard, S.O.; Lipsett, P.A.; Masur, H.; Mermel, L.A.; Pearson, M.L.; et al. Guidelines for the prevention of intravascular catheter-related infections. Clin. Infect. Dis. 2011, 52, 162-193. [CrossRef] [PubMed]

143. Mermel, L.A. What is the predominant source of intravascular catheter infections? Clin. Infect. Dis. 2011, 2, 211-212. [CrossRef] [PubMed]

144. Tong, S.Y.; Davis, J.S.; Eichenberger, E.; Holland, T.L.; Fowler, V.G., Jr. Staphylococcus aureus infections: Epidemiology, pathophysiology, clinical manifestations and management. Clin. Microbiol. Rev. 2015, 28, 603-661. [CrossRef] [PubMed]

145. Ballo, M.; Rtimi, S.; Pulgarin, C.; Hopf, N.; Berthet, A.; Kiwi, J.; Moreillon, P.; Entenza, J.; Bizzini, A. In vitro and in vivo effectiveness of an innovative silver-copper nanoparticle coating of catheters to prevent methicillin-resistant Staphylococcus aureus infection. Antimicrob. Agents Chemother. 2016, 60, 5349-5356. [CrossRef] [PubMed] 
146. Weaver, L.; Noyce, J.; Michels, H.; Keeevil, C. Potential action of Cu surfaces on meticillin-resistant Staphylococcus aureus. Appl. Microbiol. 2010, 109, 2200-2205. [CrossRef] [PubMed]

147. Zietz, C.; Fritsche, A.; Finke, B.; Stranak, V.; Haenle, M.; Hippler, R.; Mittelmeier, W.; Bader, R. Analysis of the release characteristics of $\mathrm{Cu}$-treated antimicrobial implants surface using atomic absorption spectrometry. Bioorg. Chem. Appl. 2012, 2012, 850390. [CrossRef] [PubMed]

148. Gunawan, C.; Teoh, W.; Matrquis, C.; Amal, R. Cytotoxyc Origin of Copper (II)Oxide Nanoparticles: Comparative Studies with Micron-Sized Particles, Leachate and Medical Salts. ACS Nano 2011, 5, 7214-7225. [CrossRef] [PubMed]

149. Bondarenko, O.; Juganson, K.; Ivask, A.; Kasemets, K.; Mortimer, M.; Kahru, A. Toxycity of Ag, CuO, and $\mathrm{ZnO}$ nanoparticles to selected environmentally relevant test organisms and mammalian cells in vitro: A critical review. Arch. Toxicol. 2013, 87, 1181-1200. [CrossRef] [PubMed]

150. Nguyen, T.; Park, H.; Kim, J.; Kim, H.; Lee, H.; Yoon, J.; Lee, C. Microbial inactivation by Cupric Ion in Combination with $\mathrm{H}_{2} \mathrm{O}_{2}$ : Role of Reactive Oxidants. Environ. Sci. Technol. 2013, 47, 13661-13667. [CrossRef] [PubMed]

151. Gao, G.; Pang, H.; Xu, S.; Lu, Q. Copper based nanostructures: Promising antibacterial agents and photocatalysis. Chem. Commun. 2009, 3571-3573. [CrossRef] [PubMed]

152. Gedanken, A.; Perkas, N.; Perelshtein, I.; Applerot, G.; Lipovsky, A.; Nitzan, Y.; Lubart, R. Chapter 9. Innovative Inorganic Nanoparticles with Antimicrobial Properties Attached to Textiles by Sonochemistry. In Cavitation: A Novel Energy-Efficient Technique for the Generation of Nanomaterials; Manickam, S., Ashokkumar, M., Eds.; Pan Stanford Publishing: Singapore, 2014; pp. 263-300.

153. Sedighi, A.; Montazer, M.; Samadi, N. Synthesis of nano- $\mathrm{Cu}_{2} \mathrm{O}$ on cotton: Morphological, physical, biological and optical sensing characteristics. Carbohydr. Polym. 2014, 110, 489-498. [CrossRef] [PubMed]

154. Linder, M.C. The relationship of copper to DNA damage and damage prevention in humans. Mutant. Res. 2012, 733, 83-91. [CrossRef]

155. Irie, H.; Kamiya, K.; Shibanuma, T.; Miura, S.; Tryck, D.; Yo koyama, T.; Hashimoto, K. Visible light sensitive $\mathrm{Cu}(\mathrm{II})$-grafted $\mathrm{TiO}_{2}$ photocatalysts: Activities and X-ray absorption fine structure analyses. J. Phys. Chem. C 2009, 113, 10671-10766. [CrossRef]

156. Irie, H.; Miura, S.; Kamiya, K.; Hashimoto, K. Efficient visible light-sensitive photocatalysts: Grafting Cu(II) onto $\mathrm{TiO}_{2}$ and $\mathrm{WO}_{3}$ photocatalysts. Chem. Phys. Lett. 2008, 457, 202-205. [CrossRef]

157. Ishiguro, H.; Yao, Y.; Nakano, R.; Hara, M.; Sunada, K.; Hashimoto, K.; Kajioka, J.; Fujishima, A.; Kubota, Y. Photocatalytic activity of $\mathrm{Cu}^{2+} / \mathrm{TiO}_{2}$-coated cordierite foam inactivates bacteriophages and Legionella pneumophila. Appl Catal. B 2013, 129, 56-61. [CrossRef]

158. Yates, M.H.; Brook, L.A.; Ditta, B.I.; Evans, P.; Foster, H.A.; Sheel, W.D.; Steele, A. Photo-induced self-cleaning and biocidal bahavior of titania and copper oxide multilayers. J. Photochem. Photoboiol. A 2008, 197, 197-205. [CrossRef]

159. Kelly, J.P.; Li, H.; Benson, S.P.; Whitehead, K.A.; Verran, J.; Arnell, D.R.; Iordanova, I. Comparison of the tribological and antimicrobial propertiesof $\mathrm{CrN} / \mathrm{Ag}, \mathrm{ZrN} / \mathrm{Ag}$, TiN/Ag and TiN/Cu nancomposite coatings. Surf. Coat Technol. 2010, 205, 1606-1610. [CrossRef]

160. Caballero, L.; Whitehead, A.K.; Allen, S.N.; Verran, J. Inactivation of Esherichia coli on immobilized $\mathrm{TiO}_{2}$ using fluorescent light. J. Photochem. Photobiol. A 2009, 202, 92-98. [CrossRef]

161. Kelly, P.J.; Barker, M.P.; Ostovarpour, S.; Ratova, M.; West, T.G.; Iordanova, I.; Bradley, W.J. Deposition of photocatalytic titania coatings on polymer substrates by HIPIMS. Vacuum 2012, 86, 1880-1882. [CrossRef]

162. Leyland, N.; Podporska, A.; Caroll, J.; Browne, J.; Hinder, S.; Quilty, B.; Pillai, C.S. Highly efficient F, $\mathrm{Cu}$-doped $\mathrm{TiO}_{2}$ antibacterial visible light active photocatalytic coatings to combat hospital acquired infections. Nat. Sci. Rep. 2016, 6, 24770. [CrossRef] [PubMed]

163. Ryan, D.; Pillai, S.C.; Carrol, J. Dublin Institute of Technology. A Surface Coating. U.S. Patent 9,210,934, 15 December 2015.

164. Baghriche, O.; Rtimi, S.; Pulgarin, C.; Sanjines, R.; Kiwi, J. Innovative $\mathrm{TiO}_{2} / \mathrm{Cu}$ nanosurfaces inactivating bacteria in the minute range under low intensity actinic light. ACS Appl. Mater. Interfaces 2012, 4, 5234-5240. [CrossRef] [PubMed]

165. Jeng, J.H. Swanson, Toxicity of metal oxide nanoparticles in mammalian cells. J. Environ. Sci. Health Part A Toxic. Hazard. Subst. Environ. Eng. 2006, 4, 2699-2711. [CrossRef] [PubMed] 
166. Baghriche, O.; Rtimi, S.; Pulgarin, C.; Sanjines, R.; Kiwi, J. Effect of the spectral properties of $\mathrm{TiO}_{2}, \mathrm{Cu}$, $\mathrm{TiO}_{2} / \mathrm{Cu}$ sputtered films on the bacterial inactivation under low intensity actinic light. J. Photochem. Photobiol. A 2013, 251, 50-56. [CrossRef]

167. Kiwi, J.; Morrison, C. Heterogeneous photocatalysis. Dynamics of charge transfer in lithium-doped anatase-based catalyst powders with enhanced water photocleavage under ultraviolet irradiation. J. Phys. Chem. 1984, 88, 6146-6152. [CrossRef]

168. De Romanha, D.L.; Olivares, M.; Uauy, R.; Araya, M. Risks and benefits of copper in light of new insights of copper homeostasis. J. Trace Elements Med. Biol. 2011, 25, 3-13. [CrossRef] [PubMed]

169. Rtimi, S.; Ballo, M.; Laub, D.; Pulgarin, C.; Entenza, J.; Bizzini, A.; Kiwi, J. Duality in the Eschericia coli and methicillin resistant Staphylococcus aureus reduction mechanism under actinic light on innovative co-sputtered surfaces. Appl. Catal. A 2015, 498, 185-191. [CrossRef]

170. Qiu, X.; Miyauchi, M.; Sunada, K.; Minoshima, M.; Liu, M.; Lu, Y.; Ding, M.; Shomodara, Y.; Hosogi, Y.; Kuroda, Y.; et al. Hybrid $\mathrm{Cu}_{\mathrm{x}} / \mathrm{TiO}_{2}$ nanocomposites as Risk-Reduction Materials in Indoor Environments. ACS Nano 2012, 6, 1609-1618. [CrossRef] [PubMed]

171. Grey, B.; Steck, R. Concentrations of Copper Thought to be Toxic to Esherichia coli Can Induce the Viable but Nonculturable Condition. Appl. Environ. Microbiol. 2001, 67, 5325-5327. [CrossRef] [PubMed]

172. Rtimi, S.; Pulgarin, C.; Sanjines, R.; Nadtochenko, V.; Lavanchy, J.-C.; Kiwi, J. Preparation and Mechanism of $\mathrm{Cu}$-decorated $\mathrm{TiO}_{2}-\mathrm{ZrO}_{2}$ Films Showing Accelerated Bacterial Inactivation. ACS Appl. Mater. Interfaces 2015, 7, 12832-12839. [CrossRef] [PubMed]

173. Rtimi, S.; Pulgarin, C.; Sanjines, R.; Kiwi, J. Accelerated self-cleaning by Cu-promoted binary-oxides under sunlight. Appl. Catal. B 2016, 180, 648-655. [CrossRef]

174. Neubert, S.; Mitoraj, D.; Shevlin, S.; Pulisova, P.; Heimann, M.; Du, Y.; Gregory, C.; Goh, K.; Pacia, M.; Kruczał, K.; et al. Highly efficient rutile $\mathrm{TiO}_{2}$ photocatalyst with single $\mathrm{Cu}(\mathrm{II})$ and $\mathrm{Fe}(\mathrm{III})$ surface catalytic sites. J. Mater. Chem. A 2016, 4, 3127-3133. [CrossRef]

175. Karunakaran, C.; Abiramasundari, G.; Gomathisankar, P.; Manikanda, G.; Anandi, V. Cu-doped $\mathrm{TiO}_{2}$ nanoparticles for photocaatlytic disinfection of bacteria under visible light. J. Colloid Interfaces Sci. 2010, 352, 68-74. [CrossRef] [PubMed]

176. Warnes, S.; Green, S.; Michels, H.; Keevil, C. Biocidal efficacy of copper alloys against pathogenic enterococci involves degradation of genomic and plasmid DNAs. Appl. Environ. Microbiol. 2010, 76, 5390-5401. [CrossRef] [PubMed]

177. Eshed, M.; Lellouche, J.; Matalon, S.; Gedanken, A.; Banin, M. Sonochemical coatings of ZnO and CuO nanoparticles inhibit streptococcus mutans biofilm formation on teeth model. Langmuir 2012, 28, 12288-12295. [CrossRef] [PubMed]

178. Chang, S.; Liu, W. The roles of the surface-doped metal-ions (V, Mn, Fe, Cu, Ce, and W) in the interfacial behavior of $\mathrm{TiO}_{2}$ photocatalysts. Appl. Catal. B 2014, 156-157, 466-475. [CrossRef]

179. Lemire, A.; Harrison, J.; Turner, R. Antimicrobial activity of metals: Mechanism, molecular targets and applications. Nat. Rev. Microbiol. 2013, 11, 371-384. [CrossRef] [PubMed]

180. Pham, T.; Lee, B. Disinfection of Sthphylococcus aureus in indoor aerosols using $\mathrm{Cu}^{-\mathrm{TiO}_{2}}$ deposited on glassfibers under visible light irradiation. J. Photochem. Photobiol. A 2015, 307-308, 16-22. [CrossRef]

181. Liu, L.; Giu, X.; Sun, C.; Li, H.; Deng, Y.; Gao, F.; Dong, L. In situ loading of ultrasmall $\mathrm{Cu}_{2} \mathrm{O}$ particles on $\mathrm{TiO}_{2}$ nanosheets to enhance the visible light photoactivity. Nanoscale 2012, 4, 6351-6359. [CrossRef] [PubMed]

182. Musil, J. Flexible hard nanocomposite coatings. RSC Adv. 2015, 5, 60482-60495. [CrossRef]

183. Musil, J.; Blazek, J.; Fajfrlik, K.; Cerstvy, R. Flexible antibacterial Al-Cu-N films. Surf. Coat. Technol. 2015, 264, 114-120. [CrossRef]

184. Musil, J.; Karel, M.; Fajfrlik, K.; Cerstvy, R.J. Flexible antibacterial Zr-Cu-N thin films resistant to cracking. Vac. Sci. Technol. A 2015, 34. [CrossRef]

(C) 2017 by the authors; licensee MDPI, Basel, Switzerland. This article is an open access article distributed under the terms and conditions of the Creative Commons Attribution (CC BY) license (http://creativecommons.org/licenses/by/4.0/). 